\title{
Contributory Negligence in the Twenty-First Century: An Empirical Study of First Instance Decisions
}

\author{
James Goudkamp ${ }^{\dagger}$ and Donal Nolan ${ }^{\ddagger}$
}

Keywords: Negligence; contributory negligence; apportionment of damages; Law Reform (Contributory Negligence) Act 1945; first instance decisions; empirical study.

In this article we report the results of an empirical study of 368 first instance decisions on the contributory negligence doctrine handed down in England and Wales between 2000 and 2014. The two central questions at which we looked were: how often a defendant's plea of contributory negligence was successful; and by how much a claimant's damages were reduced when a finding of contributory negligence was made. We also considered the extent to which the answers to these questions depended on the following variables: the claimant's age; the claimant's gender; the type of damage suffered by the claimant; the contextual setting of the claim; and the year of the decision. Our study uncovered several important truths about the contributory negligence doctrine hidden in this mass of case law, some of which cast significant doubt on the accuracy of widely held views about the doctrine's operation.

\section{INTRODUCTION}

The doctrine of contributory negligence reduces the compensation which the victim of a wrong receives where the victim was partly to blame for his or her own damage. Paradigmatic examples of conduct that is likely to constitute contributory negligence include failing to wear a seatbelt while a passenger in a motor vehicle, failing to check the depth of a swimming pool before diving into it, and crossing a road without looking for oncoming traffic. It is clear that the contributory negligence doctrine is one of the most important rules in English private law. ${ }^{1}$ The doctrine is frequently relied on by defendants both in litigation and in negotiating

\footnotetext{
† Associate Professor of Law, University of Oxford; Fellow and Tutor in Law, Keble College, Oxford; Academic Fellow, Inner Temple; Senior Honorary Research Fellow, University of Western Australia; Honorary Principal Fellow, University of Wollongong; Barrister, 7 King's Bench Walk.

¥ Professor of Private Law, University of Oxford; Francis Reynolds and Clarendon Fellow and Tutor in Law, Worcester College, Oxford. We are immensely grateful to Charles Austin, who bore primary responsibility for collecting and coding the data on which this paper is based, to Mengfei Ying, who worked tirelessly to check the accuracy of the data and to collect information regarding contributory negligence and apportionment from primary and secondary sources, and to Lindsay Lee, who carried out the statistical analysis. We are also greatly indebted to James Plunkett for providing us with valuable comments on a draft of this article, and to the two MLR referees for their thoughtful and constructive observations. Some of the results of this study were presented in a lecture in the Reader's Lecture Series at the Inner Temple in January 2016, and we are grateful to the audience for their helpful remarks. This research was funded by the John Fell Oxford University Press (OUP) Research Fund.

1 ' $T$ T] he defence [of contributory negligence] is used on a daily basis': J. Steele, 'Law Reform (Contributory Negligence) Act 1945: Collisions of a Different Sort' in T.T. Arvind and J. Steele (eds), Tort Law and the Legislature: Common Law, Statute and the Dynamics of Legal Change (Oxford: Hart Publishing, 2013) 165.
} 
settlements, ${ }^{2}$ and damages are regularly discounted for contributory negligence by substantial amounts (often as much as 50 per cent $^{3}$ ). With regard to settlements, it has been said that 'much of the negotiation' may involve trying to agree a discount to reflect the possibility of a finding of contributory negligence were the case to go to court. ${ }^{4}$ Two further points attest to the practical significance of the contributory negligence doctrine. One is that in personal injury cases, the doctrine has a personal impact on claimants, as it usually leaves them with uninsured losses. ${ }^{5}$ And the other is that the operation of the doctrine probably affects the public generally, through its impact on liability insurance premiums (it is plausible to think that premiums, would be higher without the doctrine, perhaps significantly so ${ }^{6}$ ). Nevertheless, despite the importance of the contributory negligence doctrine, remarkably little is known about how it works 'on the ground'. ${ }^{7}$ In order to help fill this gap, we studied 368 first instance decisions in England and Wales decided between 2000 and 2014. This sample comprised every first instance decision (both High Court and County Court) in which contributory negligence was pleaded that was handed down during the study period and which we were able to access electronically. ${ }^{8}$ This article reports and discusses our findings. It tests a range of received opinions about the judicial application of the contributory negligence doctrine against hard empirical data.

The two central questions at which we looked were: how often a defendant's plea of contributory negligence was successful; and the quantum by which a claimant's damages were reduced when a finding of contributory negligence was made. We considered the extent to which the answers to these questions depended on the following variables: the claimant's age; the claimant's gender; the type of damage suffered by the claimant (personal injury, property damage or pure economic loss); the contextual setting of the claim; and the year of the decision. We also explored various other matters. These included the distribution of discounts that the courts

\footnotetext{
2 An American study found that defendants pleaded claimant negligence in 63 per cent of the automobile accident trials surveyed: M.G. Shanley, Comparative Negligence and Jury Behavior (Santa Monica: Rand Graduate Institute, 1985) 39 .

${ }^{3}$ See the text to nn 81 and 94 below.

${ }^{4}$ P. Cane, Atiyab's Accidents, Compensation and the Law (Cambridge: CUP, 8th ed, 2013) 269.

${ }^{5}$ Where the claimant has first-party insurance - as will frequently be the case in a property damage claim - his or her contributory fault is unlikely as such to affect any insurance claim, although some types of behaviour that might amount to contributory negligence (such as drink driving) may have this effect: see ibid, 295-296.

${ }^{6}$ It has frequently been argued in the United States that the doctrine of contributory negligence should not be watered down because doing so would result in an increase in insurance premiums. The suggestion that the doctrine has some effect on insurance premiums seems to be tenable. The precise nature of any link is something with which we cannot engage properly here. For discussion, see C.J. Peck, 'Comparative Negligence and Automobile Liability Insurance' (1960) 58 Mich L Rev 689; J.G. Fleming, 'Comparative Fault at Last - By Judicial Choice' (1976) 64 Calif LR 239, 243-244; V. Schwartz, Comparative Negligence (New Providence: LexisNexis, 5th ed, 2012) para 2.04.

7 'Little is known about the quantitative effect of the law of contributory negligence': Cane, $\mathrm{n} 4$ above, 56. See also L. Barnes, 'Contributory Negligence and the Child' [2010] Jur Rev 195, 201n, remarking that there has been 'little in the way of recent studies' of the doctrine's operation.

${ }^{8}$ We explain in detail later why we focused on first instance decisions, and the importance of this methodological choice: see the text to $n 43$ below.
} 
made for contributory negligence, and the ages of the youngest and oldest claimants found guilty of contributory negligence.

Although the apportionment legislation that moulded the law of contributory negligence into its current shape was enacted throughout much of the Commonwealth in the first half of the twentieth century, ${ }^{9}$ there have been only four previous empirical investigations of the doctrine in Commonwealth jurisdictions, the most recent of which was conducted two decades ago. It is worth briefly reviewing these studies, in order to set the scene for our investigation, and to demonstrate why it is distinct. The first such study was a 1973 survey of insurance claims in the UK (excluding Northern Ireland) conducted on behalf of the Royal Commission on Civil Liability and Compensation for Personal Injury (the 'Pearson Commission'). According to this survey, 26 per cent of the settled personal injury claims were disposed of on the basis that the claimant had been guilty of contributory negligence. ${ }^{10}$ The second study was conducted for the National Committee of Inquiry on Compensation and Rehabilitation in Australia. It surveyed 2,200 personal injury liability insurance files that had been closed in four Australian states in 1972 and 1973. According to this survey, 'a significant number' of all claimants had their compensation reduced by 'substantial sums' because of contributory negligence, with more than one-fifth of all payments in cases of permanent disability being reduced. ${ }^{11}$ It was also found that when a deduction was made for contributory negligence, the average deduction was 39.5 per cent. ${ }^{12}$ The third study was a survey of settlements of personal injury claims conducted by the Oxford Centre for Socio-Legal Studies, the results of which were published in $1984 .{ }^{13}$ According to this survey, the doctrine of contributory negligence placed 'a powerful negotiating weapon in the hands of the defendant's solicitors or insurance company', which was 'extensively used', and taken into account in 45 per cent of the 51 settlements surveyed. ${ }^{14}$ Furthermore, it was found that in about a quarter of the settlements surveyed the contributory negligence doctrine had caused difficulties in the negotiation process. ${ }^{15}$ The final study was conducted by the Law Commission in 1994. The Commission surveyed victims of personal injury who had obtained compensation in settlements. ${ }^{16}$ In

\footnotetext{
9 The legislation that applies in England, Wales and Scotland is the Law Reform (Contributory Negligence) Act 1945. Legislation in many other jurisdictions is closely based on this statute.

10 Report of the Royal Commission on Civil Liability and Compensation for Personal Injury, Cmnd 7054 (1978) vol 2, 163 (Table 117).

11 Report of the National Committee of Inquiry on Compensation and Rebabilitation in Australia (Canberra: Australian Government Publishing Service, 1974) vol 1, paras 129-130. The percentage of all cases in which deductions were made for contributory negligence was however somewhat lower: ibid, vol 3, 97 (Table 13).

12 ibid, para 131.

${ }^{13}$ D. Harris et al, Compensation and Support for Illness and Injury (Oxford: Clarendon Press, 1984).

14 ibid, 91.

15 ibid, 111.

${ }^{16}$ Law Commission, Personal Injury Compensation: How Much is Enough? A Study of the Compensation Experiences of Victims of Personal Injury (Law Com No 225, 1994). About half the settlements arose out of work-related accidents or disease, and most of the remainder arose out of road accidents (ibid, para 2.1).
} 
lower value claims, 8-10 per cent of the 761 victims surveyed said that they had been held partly to blame for their injury, but this figure jumped to 19 per cent in higher value claims. ${ }^{17}$ Respondents who reported that they had been held partly responsible for their injury were generally unable to provide the percentage of the blame attributed to them, but when such a figure was given the quartile into which it most often fell was 25-49 per cent. ${ }^{18}$ In 92 cases, the survey information was matched with data from solicitors' files, ${ }^{19}$ and in 13 per cent of these cases the files indicated that the settlement had been reduced for contributory negligence, with the reductions ranging from 10 per cent to 75 per cent. ${ }^{20}$

Our study is therefore the first investigation of the practical operation of the contributory negligence doctrine for over 20 years. Furthermore, our study is very different from these earlier investigations. First, unlike the earlier studies, we are concerned not with settlements but solely with judicial decisions. ${ }^{21}$ Secondly, while we consider the operation of the doctrine of contributory negligence in all the contexts in which it operates, these studies were concerned only with personal injury claims. Thirdly, we address a greater range of issues relating to the contributory negligence doctrine: none of these studies, for example, looked at the relationships between the contributory negligence doctrine and variables such as the claimant's age and gender. A fourth difference is, however, perhaps the most important, and explains several of the others. All the earlier studies were conducted in the course of a broader inquiry into the operation of tort law as a compensation mechanism for personal injury. This explains the focus on personal injury, of course, but also the focus on settlements, as far more compensation is paid pursuant to such settlements than court decisions. In addition, it explains why the analysis of contributory negligence was relatively cursory, since the doctrine was not the central concern of these studies. They concentrated on other issues, such as whether a no-fault compensation system would be preferable to the current system, or whether the levels of compensation received by tort victims were adequate.

It is important to emphasise that our study is concerned with how judges apply the contributory negligence doctrine. The significance of this should not be underestimated. The settlement process is conducted in the 'shadow of the law'. ${ }^{22}$

\footnotetext{
17 ibid, para 4.10 (Table 407).

18 ibid.

19 ibid, para 11.7 .

20 ibid, para 11.9 .

${ }^{21}$ Although the Australian survey dealt with claims that were resolved by court verdict as well as by settlement, in none of the four states surveyed did these account for more than 10 per cent of the claims, and in two states they accounted for only 2.3 per cent of them: Report of the National Committee of Inquiry on Compensation and Rehabilitation in Australia, n 11 above, vol 3, 96 (Table 10).

22 'The formal legal rules of the law of negligence provide the structure for all [personal injury claim] negotiation': H. Genn, Hard Bargaining: Out of Court Settlement in Personal Injury Actions (Oxford: Clarendon Press, 1987) 11. For a seminal account of this relationship, see R.H. Mnookin and L. Kornhauser, 'Bargaining in the Shadow of the Law: The Case of Divorce' (1979) 88 Yale LJ 950.
} 
It follows that reliable information about judicial decisions on the doctrine of contributory negligence should facilitate the settlement of disputes by giving litigants and their advisers a clearer picture of the likely outcome of possible litigation. In particular, it is hoped that greater clarity may aid claimants, whom it has been suggested may be induced by the uncertainty surrounding the doctrine to accept low settlement offers. ${ }^{23}$ Furthermore, the frequency with which the contributory negligence doctrine arises in tort litigation means that our sample of judicial decisions on the topic is large enough for us to be able to draw meaningful conclusions about the doctrine's operation.

We also hope that this article will help judges to decide what discount to impose following a finding of contributory negligence. As we shall see, ${ }^{24}$ the vast majority of cases in which the doctrine of contributory negligence is in issue are heard in County Courts. However, County Court judgments are generally not reported or published online. Furthermore, according to conventional wisdom, appellate courts interfere with apportionment decisions only exceptionally. ${ }^{25}$ It follows that guidance from appellate judges on the appropriate range of discounts is virtually non-existent. ${ }^{26}$ As a result, there is a serious lack of transparency in the discounting process and little guidance available to trial judges. By revealing information about the discounts that courts have previously imposed for contributory negligence, our study should make the task of apportioning damages a little easier. ${ }^{27}$

\section{THE LAW OF CONTRIBUTORY NEGLIGENCE IN OUTLINE}

It will be helpful if we start by outlining the central features of the law governing contributory negligence. This discussion is intended to serve simply as a reminder of the key features of the law in this regard. A full exposition of the relevant law should be sought elsewhere. ${ }^{28}$ The first point that should be made is that contributory negligence must be pleaded by the defendant. The court cannot raise it on its own motion. ${ }^{29}$ Where contributory negligence has been pleaded, the judge engages in a two-stage analysis. At the first stage, the judge determines whether the claimant is guilty of contributory negligence. A claimant will be guilty of contributory negligence if he or she failed to take reasonable care of his or her own interests, and this contributed to the damage he or she suffered. The standard of

\footnotetext{
23 A. Mullis and K. Oliphant, Torts (Basingstoke: Palgrave Macmillan, 4th ed, 2011) 156.

24 See text to $\mathrm{n} 37$ below.

${ }^{25}$ Jackson v Murray [2015] UKSC 5, [2015] 2 All ER 805 at [31] (Lord Reed).

26 The principal exception being Froom v Butcher [1976] QB 286, where the Court of Appeal laid down guideline discounts for seatbelt cases.

${ }^{27}$ For a recent example of a court using analogous cases to help determine the appropriate discount for contributory negligence, see Sabirv Osei-Kwabena [2015] EWCA Civ 1213.

28 See, eg, W.E. Peel and J. Goudkamp, Winfield \& Jolowicz, on Tort (London Sweet \& Maxwell, 19th ed, 2014) para 23-036ff. The classic English study of contributory negligence is G.L. Williams, Joint Torts and Contributory Negligence (London: Stevens \& Sons, 1951).

${ }^{29}$ Fookes v Slaytor [1978] 1 WLR 1293.
} 
care is objective, ${ }^{30}$ although sometimes personal characteristics of the claimant are attributed to the reasonable person, such as his or her age. ${ }^{31}$

The second stage of the analysis is relevant only if the claimant is found guilty of contributory negligence. It centres on the statutory apportionment provision. This provision is found in section 1 of the Law Reform (Contributory Negligence) Act 1945, which stipulates that:

Where any person suffers damage as a result partly of his own fault and partly of the fault of any other person or persons, a claim in respect of that damage shall not be defeated by reason of the fault of the person suffering the damage, but the damages recoverable in respect thereof shall be reduced to such extent as the court thinks just and equitable having regard to the claimant's share in the responsibility for the damage.

By convention, a judge who has made a finding of contributory negligence must assess the parties' respective shares of responsibility for the damage as two percentages that add up to 100 per cent. ${ }^{32}$ The respective shares of responsibility are determined by reference to the parties' comparative blameworthiness and the relative causative potency of their faulty conduct. ${ }^{33}$ The court then reduces the claimant's damages by the percentage of responsibility that has been assigned to him or her. Judges are not supposed to treat the apportionment exercise as a scientific exercise but to approach it 'in a broad, jury-like and commonsense way'. ${ }^{34}$

\section{METHODOLOGY}

In this section of the article, we outline the methodology of our study, so that readers of this article can evaluate the methods that we used and draw their own conclusions regarding the results. We highlight both the strengths and weaknesses of our methodology. Most of the data collection and coding for this study was done by research assistants who had legal backgrounds and a sound understanding of the law of contributory negligence and tort law generally. We defined the parameters of the process, supervised it closely to ensure that the work was being done properly, and resolved issues that the research assistants brought to our attention.

\footnotetext{
30 'In determining [the issue of contributory negligence], the law eliminates the personal equation': Froom v Butcher [1976] QB 286, 294 (Lord Denning MR).

${ }^{31}$ Gough v Thorne [1966] 1 WLR 1387 (holding child claimants to the standard of a reasonable child of the same age).

32 The combined percentages must not exceed 100 per cent: Black v McCabe [1964] NI 1. Cases involving multiple defendants are subject to special rules: see Fitzgerald v Lane [1989] 1 AC 328.

33 Stapley v Gypsum Mines Ltd [1953] AC 663, 682 (Lord Reid).

${ }^{34}$ Badger v Ministry of Defence [2005] EWHC 2941 (QB), [2006] 3 All ER 173 at [16] (Stanley Burnton J). See also n 95 below.
} 


\section{The scope of the study}

Our study focused on first instance decisions of the High Court and County Courts of England and Wales. We located the relevant cases directly and indirectly. We were able to obtain decisions directly where the full text of the judgment was electronically available. We also gleaned the salient facts of many other cases indirectly either from a reported summary of the decision or, where an appeal had been brought against the judgment, from the judgment of the appellate court. ${ }^{35}$

The fact that we proceeded in this way introduced two selection biases into our study. The first selection bias arose because the decisions that were directly available were predominantly High Court decisions. This was because the proportion of High Court decisions available online greatly exceeds the proportion of County Court decisions available online. The allocation of tort cases as between the High Court and County Courts is complex, and the details are relatively unimportant for present purposes. ${ }^{36}$ It suffices to say that most tort cases are heard in the County Courts, and only higher value and more complex cases are allocated to the High Court. ${ }^{37}$ It follows that, overall, the cases which were directly accessible to us were more likely to involve larger and more complex claims than cases in the general population of claims.

The second selection bias arose because most of the decisions that were only indirectly accessible to us had been the subject of an appeal or a summary of the decision had been compiled by a law reporter, and it may well be that such cases are unrepresentative. The fact that an appeal was brought, and the fact that permission to appeal was granted, may indicate a higher value or more complex claim, but also because the very fact that a trial judge's decision was the subject of an appeal might suggest that the decision is likely to be inconsistent with the

\footnotetext{
35 Where insufficient information was supplied about any given first instance decision in the reasons of the appellate court, the case was excluded from the study: see, eg, Akers v Motor Insurers' Bureau [2003] EWCA Civ 18, [2003] Lloyds Rep IR 427. It is of course possible that any given appeal court mistakenly recounted the details of the decision at first instance. However, the risk of errors in relation to whether a finding of contributory negligence was made at first instance, and, if so, the discount that the trial judge applied to the claimant's damages, is surely minimal. These matters are usually stated very clearly by the trial judge. Moreover, draft judgments of appellate courts are often shown to the parties so that they can alert the court to any factual errors. This provides an additional reason to be confident regarding the accuracy of the essential details reported in the appellate court judgments.

36 The central provisions in this regard are CPR 2.1-2.4. See also PD 7A. For discussion, see A. Zuckerman, Zuckerman on Civil Procedure: Principles of Practice (London: Sweet \& Maxwell, 3rd ed, 2013) paras 4.7-4.9, although even this leading and comprehensive text glosses over much of the detail.

37 'Civil cases ... are mainly dealt with by county courts ... Particularly important, complex or substantial cases are instead dealt with in the High Court' (Ministry of Justice, Civil Justice Statistics Quarterly, England and Wales (2015) 3). A claim cannot be commenced in the High Court unless its value exceeds $£ 100,000$. If proceedings include a claim for damages in respect of personal injury, the value of the personal injury component must exceed $f, 50,000$ before the claim can be filed in the High Court. See PD 7A, rr 2.1-2.2.
} 
general tenor of first instance decisions. ${ }^{38}$ Similarly, the fact that a law reporter thought it worth writing a summary of a decision may indicate that the case concerned is rather different from cases in the general population.

How important are these selection biases? We investigated the extent to which the likelihood of a finding of contributory negligence and the size of the discounts imposed for contributory negligence varied both as between High Court cases and County Court cases, and as between directly and indirectly accessed cases. We also conducted statistical analysis in order to ascertain how likely it was that any such differences were attributable to chance. Contributory negligence was found in 57 per cent of High Court cases in our sample, as opposed to 64 per cent of County Court cases, and in 56 per cent of directly accessed cases, as opposed to 65 per cent of indirectly accessed cases. Statistical analysis suggests that these differences may well be down to chance. ${ }^{39}$ If this is not the case, then the more significant disparity (which is between directly and indirectly accessed cases) may be attributable to the fact that defendants are more likely to bring appeals on contributory negligence than claimants. ${ }^{40}$ It would then follow that the figures in this article on the success rate of pleas of contributory negligence may be a little higher than one would find if one looked at the general population of cases. Differences were also observed in the average discounts imposed in High Court cases (38 per cent) and cases that were directly accessed ( 35 per cent) on the one hand and in County Court cases (45 per cent) and indirectly accessed cases (46 per cent) on the other hand. This time statistical analysis suggested that these disparities were very unlikely to be attributable to chance. ${ }^{41}$ Again, the greater disparity exists between directly and indirectly accessed cases. The explanation here might be that an appeal on contributory negligence is more likely where a substantial discount has been made at first instance, since this will usually mean that more is at stake. In any case, it seems quite likely that the average discount figures in this article may again be a little higher than one would find if one looked at the general population of first instance decisions. Despite these caveats, we feel confident that the cases in our sample are reasonably representative of the general

\footnotetext{
38 Litigants require permission to appeal. The core rules in this regard are contained in CPR 52. CPR 52.3(6) stipulates that 'Permission to appeal may be given only where - (a) the court considers that the appeal would have a real prospect of success; or (b) there is some other compelling reason why the appeal should be heard.'

39 The statistical tests returned what are known as p-values. It is convenient to introduce the concept of p-values below: see $n$ 75. Here, we simply report the values. A Pearson's chi-square test of the difference in the frequency with which contributory negligence was found as between High Court cases and County Court cases yielded a pvalue of 0.197 . The $\mathrm{p}$-value produced by the same test carried out in relation to the mode by which cases were accessed was 0.077 .

${ }^{40}$ We are conducting a separate study of contributory negligence in the appellate context. Defendants brought twothirds of the appeals in the sample of cases at which we looked.

${ }^{41}$ A two-sided t-test comparing the average discounts in High Court cases and County Court cases returned a pvalue of 0.009 . The $\mathrm{p}$-value fell to 0.004 when we ran a Wilcoxon rank sum test with continuity correction. The $\mathrm{p}$ values for the same tests comparing the average discount for directly accessed cases and indirectly accessed cases were $<0.001$.
} 
population of relevant cases. ${ }^{42}$ After all, there is a good chance that the selection biases in fact have no bearing on the incidence with which contributory negligence is found, and it is also worth emphasising that the two biases may to some extent offset each other. This is because including indirectly accessed cases considerably increased the number of County Court decisions in the sample, while the vast majority of the cases that we accessed directly were not the subject of an appeal. Nevertheless, the selection biases that we have identified should be borne in mind in interpreting our results.

The study was limited to cases decided between 1 January 2000 and 31 December 2014. ${ }^{43}$ There were three main reasons why we chose to look at decisions made during this period: first, we were interested in the contemporary operation of the doctrine; secondly, a fifteen-year period produced a sufficiently large sample of cases to enable us to make meaningful claims about the operation of the doctrine; and, thirdly, since 2000 there has been an explosion in the online availability of decisions. Making use of online decisions made the data collection process vastly less expensive and time-consuming than it would otherwise have been.

Finally, there were three reasons why we focussed on the operation of the contributory negligence doctrine at first instance, rather than in appellate courts. First, we are conducting a separate study of appellate decisions on contributory negligence, ${ }^{44}$ and it seemed less cumbersome to report the findings of that study in a freestanding article. Secondly, the doctrine of contributory negligence is obviously in issue far more frequently in absolute terms at first instance than on appeal for the simple reason that only a fraction of the cases that are heard at first instance are the subject of an appeal. This meant that by focusing on first instance decisions we were able to draw upon a much larger number of cases. And finally, very little is known about how the doctrine of contributory negligence is applied by trial judges. Discussions of contributory negligence in textbooks tend, understandably, to focus on the decisions of appellate courts. This made an investigation of the operation of the doctrine at the trial court level particularly valuable.

\footnotetext{
${ }^{42}$ It is worth remembering that '[a]ll empirical studies are imperfect, especially observational (non-experimental) social science studies' and that the goal in selecting cases 'is not a perfect match between sample frame and research conclusions, but only a reasonable connection between the two' (M.A. Hall and R.F. Wright, 'Systematic Content Analysis of Judicial Opinions' (2008) 96 Calif L Rev 63, 105).

${ }^{43}$ In cases where the salient facts of a first instance decision were gleaned from the judgment of an appellate court, the date of the first instance decision was often given by the appeal court. Where it was not, the decision date was estimated using the following method. We calculated the average number of days that passed between the date of first instance decisions and appellate decisions, using the cases for which the dates of both of those decisions were known (this came to 328 days). We then subtracted this number of days from the date of the appellate decision, in order to produce an estimated date for first instance decisions of unknown dates. A note was added in the notes column on the spreadsheet that the date of the first instance decision had been estimated.

${ }^{44}$ See n 40 , above.
} 


\section{Finding the cases}

Cases within the scope of our study were entered into a spreadsheet. In order to locate the cases in which we were interested, 'contributory negligence' was entered as a search term into LexisNexis, and the results were then ordered by date. The full text dialogue box was used (that is to say, we did not enter these search terms merely into, for example, the catchword dialogue box). Searches were also run using the phrases 'apportionment' and 'Law Reform Contributory Negligence Act 1945 ' to ensure that no relevant cases were omitted. A cross-check was then run with Westlaw, and additional cases added to the sample as necessary. All the search results were then filtered so that the only cases left were those in which the court made a formal determination as to whether or not the claimant was guilty of contributory negligence. Cases in which contributory negligence was pleaded in response to a counter-claim ${ }^{45}$ or cross-claim $^{46}$ were included. Where a deduction for contributory negligence had been agreed by the parties, the case was included only if the agreement had been formally approved by the judge because the claimant was a protected party. ${ }^{47}$ Where a case involved multiple claimants or multiple defendants ${ }^{48}$ we created separate entries for each individual claim in which contributory negligence was an issue. ${ }^{49}$ This reflected the fact that in such cases claims that are technically distinct from each other are joined together in the same set of proceedings merely for reasons of convenience. Accordingly, from this point onwards we use the language of 'claims' rather than 'cases'.

The following categories of claim were excluded from the study:

(1) Claims where the first instance decision on contributory negligence was a contingent finding that did not affect the outcome of the claim at that stage. When a trial judge determines that there is no liability on the part of the defendant, the judge will nevertheless often proceed to consider issues that would have arisen had the defendant been found liable - such as the doctrine of contributory negligence - in case the decision on liability is reversed on appeal. ${ }^{50}$ Where the issue of contributory negligence arose only in this contingent way, we did not include the claim in our study. This was partly because we were concerned that in claims of this kind the trial judge might

\footnotetext{
45 See, eg, Logical Computer Supplies Ltd v Euro Car Parks Ltd (High Court, 19 June 2001); Withers LLP v Harrison [2010] EWHC 2769 (QB).

${ }^{46}$ See, eg, Dunlop Haywards Ltd v Barbon Insurance Group Ltd [2009] EWHC 2900 (Comm), [2010] Lloyds Rep IR 149.

47 There were three such cases: Al Gouri v Achkar [2007] CLY 3079; Edwards v Martin [2010] EWHC 570 (QB); and Ali v Caton [2013] EWHC 1730 (QB).

48 We did not treat actions brought against an employee and his or her employer as involving multiple defendants since, in reality, the employer is the only defendant in such cases.

49 There were five cases involving multiple claimants and 16 involving multiple defendants.

50 The practice is not universal, however. There are numerous cases in which judges who have absolved the defendant of liability have explicitly refused to address the issue of contributory negligence, sometimes on the basis that their finding on liability made it impossible sensibly to consider the criteria of relative blameworthiness and causal potency: see, eg, Norman v Theodore Goddard [1992] BCC 14, 27 (Hoffmann J); Webster v Ridgeway Foundation School [2010] EWHC 157 (QB) at [196] (Nicol J).
} 
not engage with the contributory negligence question as fully and thoroughly as in claims where the decision on contributory negligence would affect the outcome of the first instance decision. Our sense from reading the relevant cases is that when judges appear confident in their conclusion that the defendant was not liable at all the treatment of contributory negligence is very perfunctory. ${ }^{51}$ Judges who address the issue of contributory negligence contingently sometimes give only a rough indication of the size of the discount that they may have imposed but do not descend to specific percentages. ${ }^{52}$ We also felt justified in excluding from consideration contingent rulings regarding contributory negligence given that our sample is more than large enough for one to be confident that it is representative of the wide population of claims.

(2) Professional negligence claims concerning an underlying claim in which contributory negligence was potentially an issue. We encountered several claims that had the following structure: (i) a claimant brought proceedings against his or her former lawyers alleging that the lawyers were negligent in handling an action that the claimant had against a third party, with the result that the action failed, or that the damages awarded were less than they should have been; and (ii) the lawyers sought to diminish their liability by arguing that the claimant's action against the third party would have been affected by the claimant's contributory negligence. ${ }^{53}$ Professional negligence claims with this structure were excluded from our study.

(3) Claims where the judge discussed contributory negligence, but did not make a formal determination on the issue. Examples include a discussion of the possibility of the claimant being guilty of contributory negligence in an application for an interim remedy ${ }^{54}$ or summary judgment.

(4) Claims in which the only determination pertaining to contributory negligence was whether the doctrine applied to the cause of action for which the claimant was suing. ${ }^{55}$ Judges have been called on periodically to decide whether the doctrine of contributory negligence applies to a particular cause of action, such as battery and deceit. We did not include such claims in our study unless the judge in question proceeded to make a formal determination as to whether the claimant was guilty of contributory negligence on the facts of the case. ${ }^{56}$

\footnotetext{
${ }^{51}$ Good illustrations include Joyce v O’Brien [2012] EWHC 1324 (QB), [2012] PIQR P18 at [48] (Cooke J); Vaughan v Ministry of Defence [2015] EWHC 1404 (QB) at [38] (Davis J). In these cases, it was held that the defendant was not liable, and the contingently relevant question of contributory negligence was addressed within the space of just a single paragraph. See also Sutherland v McConechy's Tyre Service Ltd [2012] CSOH 28, 2012 Rep LR 46 at [54]-[56] (Lord Stewart).

52 See, eg, Calvert v William Hill Credit Ltd [2008] EWHC 454 (Ch) at [218] (Briggs J) (stating that had the defendant been liable a 'very large' discount for contributory negligence would have been imposed).

53 See, eg, Hunter v Earnshaw [2001] PNLR 42.

54 See, eg, Morris v Buckle (t/ a Melplash Court Farm) 2004 WL 1640368.

55 See, eg, Hurst v Hone [2010] EWHC 1159 (QB) (deceit).

${ }^{56}$ See, eg, Parmer v Big Security Co Ltd [2008] EWHC 1414 (QB) (battery).
} 
(5) Claims in which the contributory negligence question was governed by foreign law. We encountered several claims in which an English court was required to consider the doctrine of contributory negligence as it applied in a foreign jurisdiction. ${ }^{57} \mathrm{We}$ excluded such claims from our study. This was because our interest lay in the doctrine of contributory negligence as recognised in English law.

The total number of claims in the spreadsheet was 368. Of these, 145 were decided in the County Court and 223 were decided in the High Court. 195 claims were directly accessed while 173 were accessed indirectly.

\section{Coding the claims}

The research assistants scrutinised the decisions in the sample in order to ascertain whether the plea of contributory negligence succeeded and, if so, the discount that the judge had applied to the damages award as a result. They also abstracted other relevant information from the judgments and populated the spreadsheet accordingly. The twelve columns in the spreadsheet (A-M) were as follows:

\section{A: The name of the case.}

B: The citation of the case. Where the first instance data had been gleaned from an appellate decision, and no neutral citation or report citation of the first instance decision was available, the citation details of the appellate decision were entered.

C: The date of the decision. Where we had had to estimate the date of the decision, ${ }^{58}$ the estimated date was entered.

\section{D: The court that decided the case.}

E: The type of claim. The categories of claim were: (1) road accident; (2) employers' liability; ${ }^{59}$ (3) occupiers' liability; ${ }^{60}$ (4) public liability; ${ }^{61}$ (5) professional negligence; (6) sports injury; and (7) other. If a claim was capable of being classified in more

\footnotetext{
${ }^{57}$ See, eg, Barings Plc (In Liquidation) v Coopers \& Lybrand (No 7) [2003] EWHC 1319 (Ch), [2003] Lloyd's Rep IR 566; Vann v Ocidental-Companbia De Seguros SA [2015] EWCA Civ 572.

${ }^{58}$ See $\mathrm{n} 43$ above.

${ }^{59}$ Defined as claims in which the defendant was sued in their capacity as the claimant's employer. This was extended to relationships akin to employment: see, eg, Commissioner of Police of the Metropolis v Lennon [2004] EWCA Civ 130, [2004] ICR 1114 (police officer suing Metropolitan Police Commissioner for failing to give advice about preservation of housing allowance entitlement).

${ }^{60}$ Defined as claims in which the defendant was sued in their capacity as the occupier of premises. Applying this definition, several claims where the claimant had suffered injury because of an alleged defect in premises in which she was staying were classified as 'other' (claim type (7)) because the defendant was not sued as the occupier of the premises but in some other capacity, typically that of a tour operator in a contractual relationship with the claimant.

${ }^{61}$ Defined as claims in which the defendant was sued in their capacity as a public authority.
} 
than one category, we made a judgment as to which classification was the most appropriate. ${ }^{62}$

F: The nature of the damage suffered by the claimant. The categories of damage were: (1) personal injury (including fatal accident and psychiatric injury claims ${ }^{63}$ ); (2) property damage; and (3) pure economic loss. Where a single action was brought in respect of more than one type of damage, we treated this as two separate claims.

\section{G: Whether a finding of contributory negligence was made.}

$\mathrm{H}$ : Where a finding of contributory negligence had been made, the percentage by which the claimant's damages were discounted as a result.

I: The claimant's gender. Where the claimant was not a natural person, the cell was left blank. Where the claim was in respect of a fatal accident, the gender of the deceased was given.

$\mathrm{J}$ : The claimant's age at the time that the damage was suffered. Fractions of years were given where they were available. This was done primarily because the courts have often made a point of recording fractions of years, especially in the case of children, the implication being that even small differences in the age of a child can make a difference to findings of contributory negligence and apportionment. These fractions were rounded to the nearest quarter of a year. If the precise age of the claimant was unknown, or if the alleged contributory negligence persisted for over 10 years ${ }^{64}$ then either 'Child' or 'Adult' was entered where it was clear that the claimant had been under or over 18 years of age at the relevant time or throughout the relevant time period. ${ }^{65}$ In some claims where the claimant's age was not apparent from the court's judgment, it was possible to obtain it from another source, such as a contemporary news report. The age thus obtained was then entered in the age column, and the source of the information recorded in the notes

\footnotetext{
${ }^{62}$ If an employer, occupier or public authority was sued in that capacity, the claim was always classified as a type (2), (3) or (4) claim respectively, even if (for example) the claim also involved a road accident or sports injury. This decision was made because our sense from reading the decisions in the (relatively uncommon) claims concerned was that the capacity in which the defendant was sued was the best and most straightforward guide as to how the claim in question should be categorised.

${ }^{63}$ At an early stage in the study, psychiatric injury claims were treated as a separate category, but as there were very few claims in this category we decided to merge it with category (1), which had originally been 'physical injury claims'.

64 The most common example of an act of contributory negligence that persisted over a long time period was smoking: see, eg, Badger n 34 above. In one claim, the alleged contributory negligence extended over a period of three years, and in this instance we entered the claimant's median age in this period. Where we could tell that the age of the claimant was one of two years we split the difference (so, for example, in the case of a claimant who must have been aged 46 or 47 years we treated the claimant as being aged 46.5 years).

${ }^{65}$ We erred on the side of caution here, and entered 'Child' or 'Adult' only if we were virtually certain that this was the case.
} 
column. Where the claim was in respect of a fatal accident, the age of the deceased at the time of the event that led to the deceased's death was given. Where the claimant was not a natural person, the cell was left blank.

$\mathrm{K}: A$ brief description of the act or (where contributory negligence was not found) alleged act of contributory negligence. Examples include 'Failure to wear a seatbelt'; 'Failure to keep a proper lookout'; 'Speeding'; 'Lying in the road while intoxicated'; 'Failure to have ladder properly footed'; 'Smoking'; 'Rushing down stairs'; and 'Failure to check architect's drawing'. The research assistants were instructed to try to maintain some consistency in the formulae used in this column. Where multiple acts of contributory negligence were found or alleged, this was noted, but only the most significant such acts were entered. Where the plea of contributory negligence succeeded, only those acts that the court found amounted to contributory negligence were entered.

\section{$\mathrm{L}:$ A brief description of the wrongful conduct of the defendant.}

M: Notes. Any interesting or unusual features of the claim were entered in this cell, and also such matters as the fact that contributory negligence had been pleaded in response to a counter-claim or cross-claim, and the fact that either the existence of contributory negligence and/or the discount had been agreed by the parties.

\section{Checking the data}

The data were collected and coded by a research assistant. In order to confirm that the research assistant was not incorrectly excluding claims from the sample, we instructed the assistant to send us a list of the claims that contained at least one of the relevant search terms but which he thought should be excluded from the sample on the ground that they did not meet the criteria we had prescribed for inclusion. We checked a random sample of 15 of these claims to determine whether he had been right to exclude them. We were satisfied that he had proceeded correctly in respect of all of the claims.

Following the initial coding of the first group of 30 claims, we checked the results against the claims themselves. This process led to the identification of some errors (which were corrected) and also to clarification of some of the coding instructions. A further 30 claims were then coded by the research assistant, and all of these were again checked by us. Following this, the research assistant coded the remainder of the claims. The research assistant was told that if any difficulties were encountered during the coding process, they should be referred to us for resolution (he consulted us intermittently when he had doubts as to how to proceed and we resolved the relevant query). Following the population of the spreadsheet by the first research assistant, the entirety of the spreadsheet was checked against the 
claims by a second research assistant. Possible errors identified by this second research assistant were brought to our attention and we then decided whether an error had been made, and, if so, modified the spreadsheet accordingly. As the foregoing reveals, all entries in the spreadsheet were double-checked by different people and a significant percentage were triple-checked, again by different people.

\section{Statistical analysis}

The data were analysed by a trained statistician. The statistician used a statistical programme known as ' $R$ ' to run the tests and to produce the graphs. She ran Pearson's chi-square tests to test independence between categorical variables (such as the frequency with which claimants were found guilty of contributory negligence) and t-tests or analysis of variance (ANOVA) as appropriate to measure the significance of observed disparities in the values of continuous variables (such as the size of discounts for contributory negligence) across different categories of data (such as male claimants and female claimants). Wilcoxon rank sum tests with continuity correction were run as a cross-check of the results produced by the ttests. Linear and logistic regression analyses were conducted in order to control for confounding variables.

\section{RESULTS}

In this section of the article, we present the results of our study. We begin by setting out some general information about the claims in the sample, and then proceed to the findings. We divide our discussion of the findings into four parts: the success rate of the plea of contributory negligence; the discount applied when contributory negligence is found; the relationship between contributory negligence and claimant age; and the relationship between contributory negligence and claimant gender. Our primary aim in this section of the article is simply to present the study's findings, although we do also make some observations about their importance. Fuller discussion of key findings in the light of the case law and academic literature is postponed until the following section of the article.

\section{General information}

Our spreadsheet contained entries for 368 claims in which the defendant had pleaded contributory negligence. ${ }^{66}$ As seen in Figure 1, most of these claims $(86$ per cent) were for personal injury, with the remaining claims being in respect of pure economic loss (10 per cent) or property damage (4 per cent). The small number of property damage claims in our sample should be borne in mind when assessing the results concerning that type of damage. It is impossible to know for certain why

${ }^{66}$ A list of claims is set out in the appendix. 
there were so few property damage claims. One plausible explanation for the small number of property damage claims in our sample is the fact that many property damage claims are likely to be relatively low value. ${ }^{67}$ This is significant because claimants may be less inclined to commence proceedings in respect of lower value claims, and defendants may be more inclined to settle such claims when proceedings are brought. Furthermore, lower value claims are determined in the County Courts and, as we observed above, County Court decisions, because of their relative inaccessibility, are under-represented in our study.

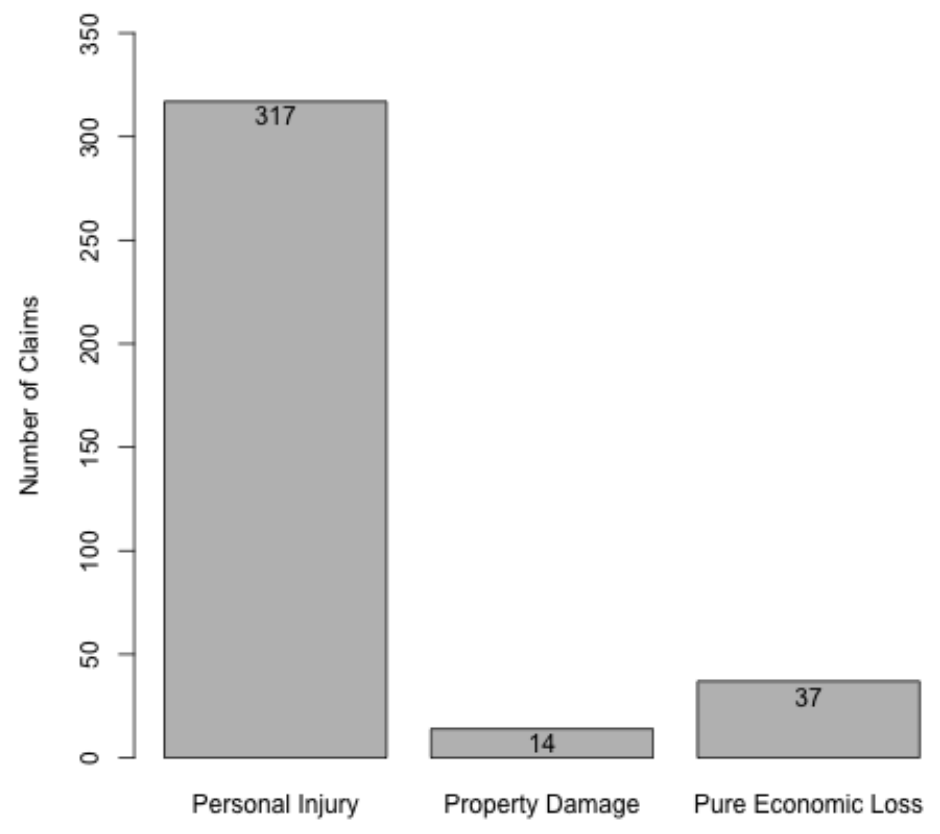

Figure 1 Number of claims by damage type

There was a slightly more even spread of the claims across our seven categories of claim type (or contextual setting), as seen in Figure 2. Nevertheless, road accident claims were by far the most common type of claim ( 39 per cent of claims), followed by employers' liability claims (23 per cent), professional negligence claims (11 per cent) and occupiers' liability claims (10 per cent). The 63 claims in the three remaining categories (public liability, sports injury and other) amount to only 17 per cent of all the claims in the sample. Once again, the small number of claims in these categories must be kept in mind when assessing the relevant results. Claims in the 'other' category included several claims arising out of collisions at

\footnotetext{
${ }^{67}$ The Department of Transport publishes estimates annually regarding the cost to society of personal injury and property damage resulting from road accidents. The cost to society per accident involving only property damage pales in comparison to the cost of even trivial personal injuries: see Department of Transport, Reported Road Casualties Great Britain: 2014 Annual Report (2015) 379-382: https://www.gov.uk/government/uploads/system/uploads/attachment data/file/467465/rrcgb-2014.pdf (accessed 14 January 2016).
} 
sea, as well as train accidents and accidents in a prison. This category also included claims where the cause of action was not common law negligence, but another tort, such as battery, false imprisonment or nuisance, and claims for pre-contractual misrepresentation under section 2(1) of the Misrepresentation Act 1967. ${ }^{68}$ The prevalence of road accident and employers' liability claims in the sample is unsurprising, as these are contexts where liability insurance is compulsory, and claims in these two categories 'probably constitute by far the largest proportion of personal injury actions which receive a full trial. ${ }^{69}$

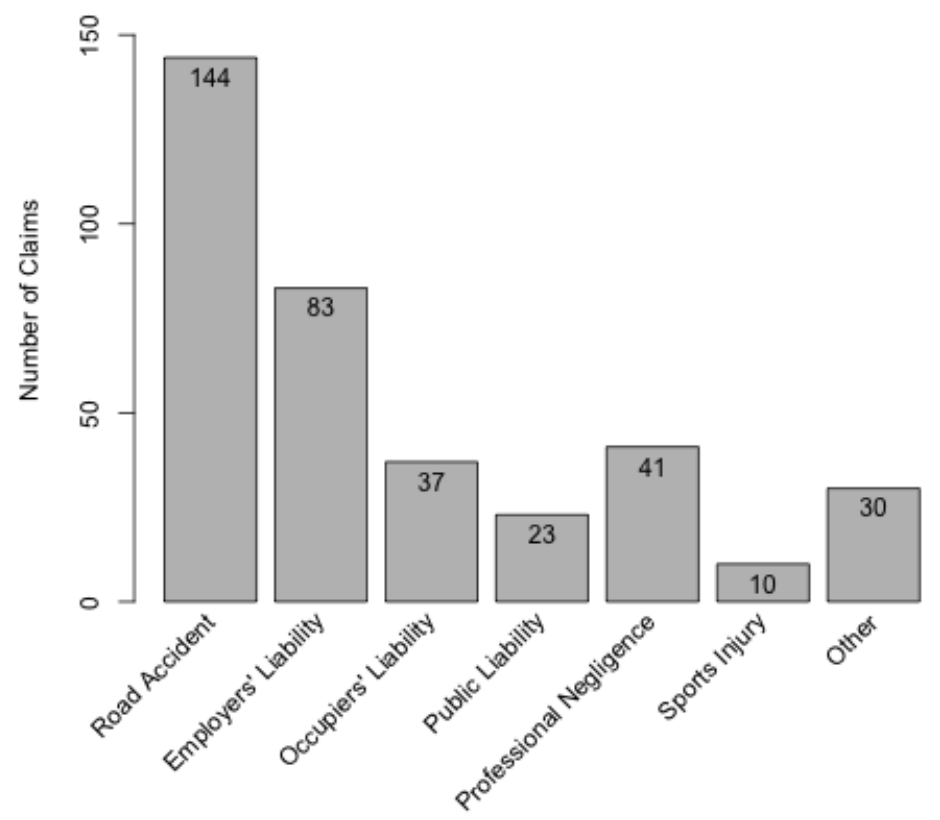

Figure 2 Number of claims by claim type

The relatively small number of occupiers' liability and public liability claims is, however, noteworthy. Previous studies suggest that claims in these two categories account for some 10 per cent of all personal injury claims, a slightly higher proportion than employers' liability claims. ${ }^{70}$ And yet in our sample there were considerably more claims in the employers' liability category than in these two

\footnotetext{
${ }^{68}$ Note that in the case of battery it has now been held that contributory negligence is not a defence to the cause of action: Co-Operative Group (CSW) Ltd v Pritchard [2011] EWCA Civ 329, [2012] QB 320. However, the relevant claim in our study (Parmer $\mathrm{n} 56$ above) pre-dated that ruling, and was decided on the basis that the defence was available.

${ }^{69}$ Cane, n 4 above, 203. According to the Compensation Recovery Unit (CRU), what it calls 'Motor' claims accounted for 78 per cent of all personal injury claims registered with the CRU in the period 2010-2015: https://www.gov.uk/government/publications/compensation-recovery-unit-performance-data (accessed 14 January 2016).

${ }^{70}$ Cane, $\mathrm{n} 4$ above, 204-205. According to the CRU, the total number of employers' liability claims registered with the CRU in the period 2010-2015 was 468,627, while the total number of 'public liability' claims (a category roughly equivalent to our 'occupiers' liability' and 'public liability' categories combined) was 506,369: see https://www.gov.uk/government/publications/compensation-recovery-unit-performance-data $\quad$ (accessed 14 January 2016).
} 
categories combined. This disparity might be attributable to (1) the fact that a higher proportion of employers' liability claims reach trial; (2) the fact that a higher proportion of employers' liability claims are tried in the High Court (High Court claims being over-represented in our sample); ${ }^{71}$ and/or (3) the fact that contributory negligence is pleaded more frequently in employers' liability claims.

Finally, we should note that we initially coded for two other categories of claims: product liability and medical negligence. However, there was only one product liability claim in the sample, ${ }^{72}$ and only two medical negligence claims. ${ }^{73} \mathrm{We}$ therefore decided to eliminate both of these categories from the spreadsheet, and added the product liability claim to the 'other' category and the medical negligence claims to the professional negligence category (which had originally been a 'professional negligence (non-medical)' category). Our study therefore suggests that these are contexts in which pleas of contributory negligence are rare, ${ }^{74}$ although the dearth of product liability claims may also reflect the small number of such claims that have been litigated in recent times.

\section{Success rate of the plea of contributory negligence}

Out of the 368 claims in our sample, the plea of contributory negligence succeeded in 221 claims (60 per cent) and failed in 147 claims (40 per cent). As shown in Figure 3, the success rate of the plea of contributory negligence is almost identical for personal injury claims and property damage claims (64 per cent in both instances), but markedly lower in pure economic loss claims (22 per cent). Statistical analysis suggests that this disparity is unlikely to be attributable to chance. $^{75}$

\footnotetext{
${ }^{71}$ See text to $\mathrm{n} 36$ above.

72 Abouzaid v Mothercare (UK) Ltd (Mayor's and City of London CC, 30 May 2000). The plea of contributory negligence in this claim failed.

73 The two medical negligence claims were Pidgeon v Doncaster HA [2002] Lloyd's Rep Med 130 and Re P (deceased) [2011] EWHC 1266 (QB). The plea of contributory negligence succeeded in Pidgeon $v$ Doncaster HA, and failed in Re P.

74 Although section 6(4) of the Consumer Protection Act 1987 makes it clear that contributory negligence is a defence to an action for damages under the strict product liability regime introduced by that Act, we are not aware of any claims in which a claimant under that legislation has had his or her damages reduced for contributory negligence. There are, however, some claims that pre-date our study where contributory negligence has been found in a product liability action brought in common law negligence: see, eg, Devilez v Boots Pure Drug Co Ltd (1962) 106 Sol Jo 552. As for medical negligence, the dearth of claims in our sample is unsurprising when one considers that Pidgeon $\mathrm{n} 73$ above (one of the two medical negligence claims in our sample) is apparently the only reported English clinical negligence claim in which there was a finding of contributory negligence: see J. Herring and C. Foster, 'Blaming the Patient: Contributory Negligence in Medical Malpractice Litigation' (2009) 25 Professional Negligence 76, 76.

75 A Pearson's chi-square test on the null hypothesis that the success rate of the plea of contributory negligence is the same across all types of damage gave a p-value of $<0.001$. A p-value is the probability of obtaining an effect at least as extreme as the one in the sample data, assuming the truth of the null hypothesis. Hence, the lower the pvalue, the more likely it is that the null hypothesis is false. The p-value in this instance is very low, which strongly suggests that the observed disparity is not attributable to chance (in the form of the sample of claims we happened to survey), so that the data provide strong evidence that the success rate of the plea does indeed vary across the different damage types. This evidence is reinforced by logistic regression analysis. This analysis showed that when
} 


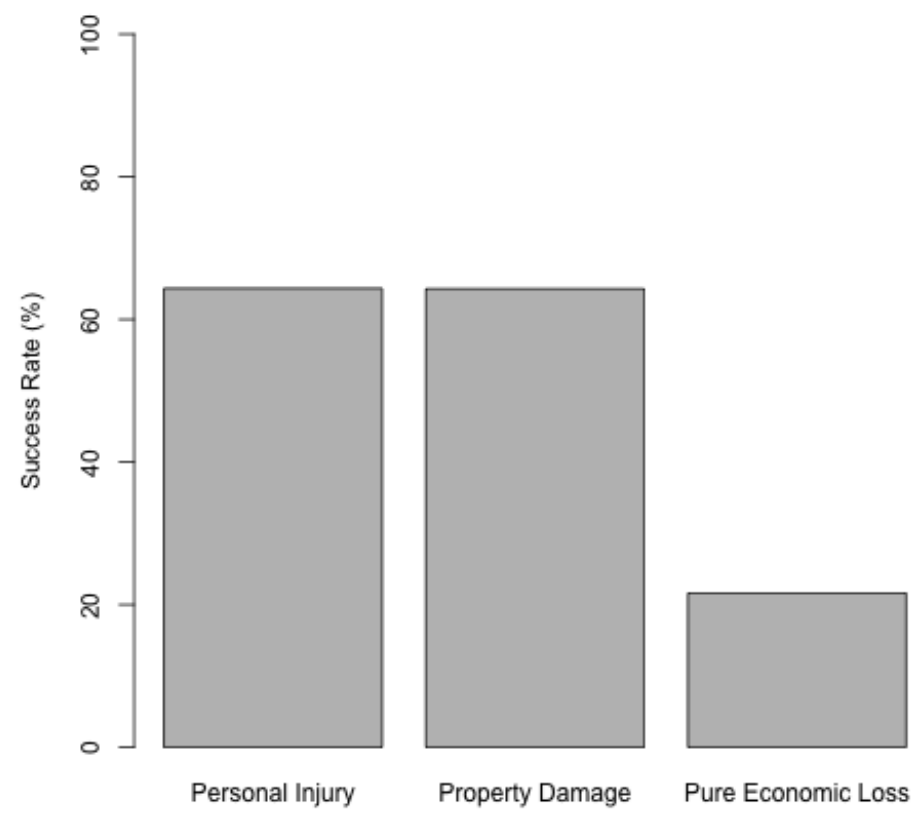

Figure 3 Success rate of plea by damage type

A possible explanation for the difference in the success rate of the plea of contributory negligence between personal injury and property damages claims on the one hand, and pure economic loss claims on the other hand, emerges when we break down the success rate of the plea by type of claim (Figure 4). This reveals that the plea of contributory negligence has a very low success rate in professional negligence claims ( 29 per cent). This success rate is roughly half that of the success rate of the plea across all types of claim in our study. Again, statistically, this difference is unlikely to be down to chance. ${ }^{76}$ The reason for the close association between the success rate in pure economic loss claims and in professional negligence claims is not hard to find. Of the 37 pure economic loss claims, the vast majority (33 claims) fell into the professional negligence category; similarly, of the 41 professional negligence claims, the preponderance (33 claims) were for pure economic loss.

\footnotetext{
pure economic loss claims were compared with personal injury claims, the odds of a finding of contributory negligence were notably lower in pure economic loss claims $(p<0.001)$. In many academic disciplines, a $p$-value of less than 0.05 is regarded as statistically significant, but the appropriateness of the use of this test of statistical significance in legal contexts has been questioned, and properly so in our view: see N.B. Cohen, 'Confidence in Probability: Burdens of Persuasion in a World of Imperfect Knowledge' (1985) 60 NYU L Rev 385, 412; D.H. Kaye, 'Is Proof of Statistical Significance Relevant?' (1986) 61 Wash L Rev 1333, 1342-1345; D.W. Vick, 'Statistical Significance and the Significance of Statistics' (2000) 116 LQR 575. Accordingly, in this article we eschew the language of 'statistical significance' in this binary sense and instead provide the $\mathrm{p}$-values themselves in the footnotes, and more general observations on the cogency of a given finding in the text.

76 Pearson's chi-square test, $\mathrm{p}<0.001$. And logistic regression analysis showed that when professional negligence claims were compared with road accident claims (the largest category of claim), the odds of a finding of contributory negligence were markedly lower in professional negligence claims $(\mathrm{p}<0.001)$.
} 


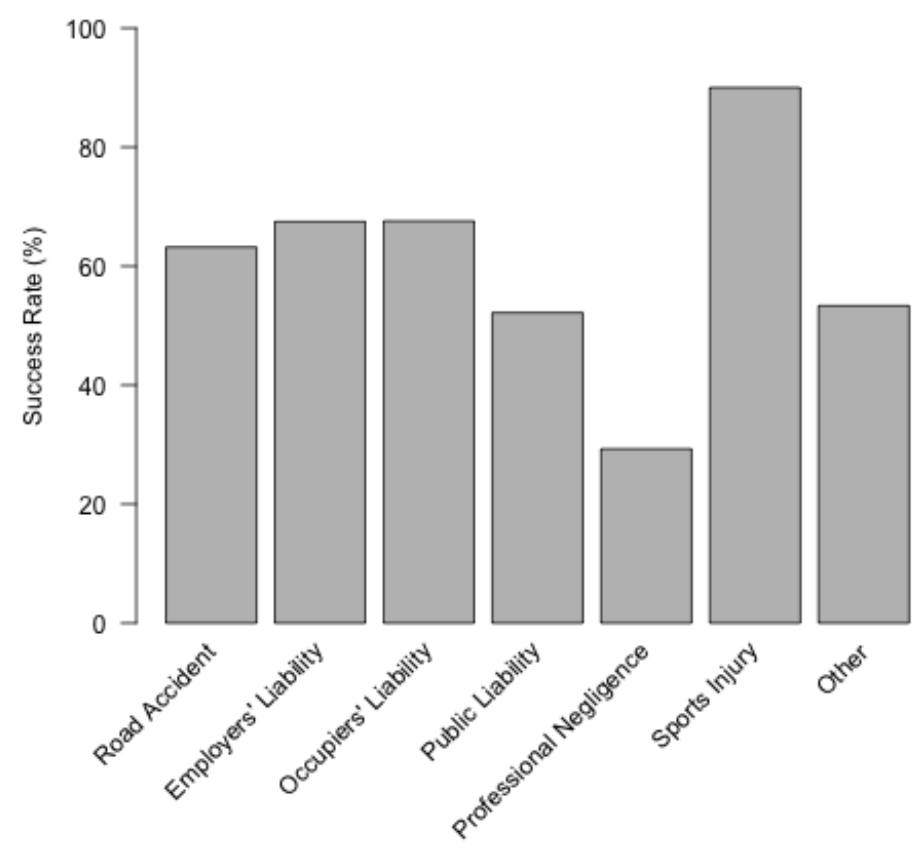

Figure 4 Success rate of plea by claim type

The other noteworthy feature of Figure 4 is the very high success rate of the plea of contributory negligence in sports injury claims ( 90 per cent). However, although our study provides some evidence of an association between this type of claim and the success rate of a plea of contributory negligence, ${ }^{77}$ this result should be interpreted cautiously as there were very few sports injury claims in the sample (10 claims). The success rates in the other five categories of claim were fairly similar to each other, as follows: road accident claims, 63 per cent; employers' liability claims, 68 per cent; occupiers' liability claims, 68 per cent; ${ }^{78}$ public liability claims, 52 per cent; and other claims, 53 per cent. ${ }^{79}$

Finally, Figure 5 shows the success rate of the plea of contributory negligence by year. We limited this graph to personal injury claims because we thought that in

\footnotetext{
${ }^{77}$ Logistic regression analysis revealed that when sports injury claims were compared with road accident claims, the odds of a finding of contributory negligence were higher in sports injury claims $(\mathrm{p}=0.121)$.

${ }^{78}$ We disaggregated the occupiers' liability category into claims by visitors and non-visitors. 65 per cent of claims by visitors resulted in a finding of contributory negligence. 100 per cent of non-visitors were found guilty of contributory negligence, although little weight should be placed on this result as there were only 3 non-visitor claims in our study. Unsurprisingly, in view of the small number of non-visitor claims, statistical analysis suggested that there was a high likelihood that the difference in the success rate of the plea of contributory negligence in visitor and non-visitor claims was down to chance (Pearson's chi-square test, $\mathrm{p}=0.543$ ).

79 The disparities between these categories may well be down to chance. For example, logistic regression analysis showed that when public liability claims were compared with road accident claims, the odds of a finding of contributory negligence were lower in public liability claims, but the $p$-value was too high $(p=0.315)$ for much to be made of this difference. And while the p-value dropped a little when we controlled for damage type, age and gender $(\mathrm{p}=0.259)$, this $\mathrm{p}$-value is still too high for us to be confident that the disparity is not down to chance.
} 
certain years media and political attention on an alleged proliferation of tort claims and a so-called 'compensation culture' might have caused judges to take a harsher view of alleged contributory fault in the personal injury context. However, statistical analysis suggests that there is no association between success rate of the plea and year in personal injury claims. ${ }^{80}$

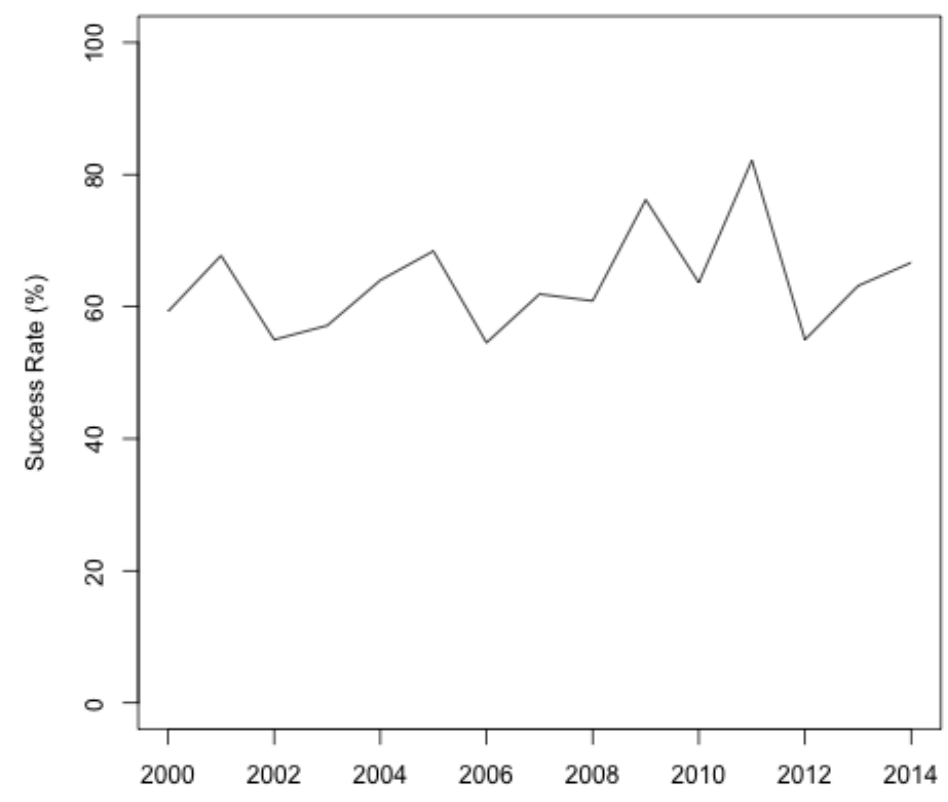

Figure 5 Success rate of plea by year (personal injury claims)

\section{Discount where contributory negligence found}

In the 221 claims in which the claimant was found guilty of contributory negligence, the average amount by which the claimant's damages were reduced was 40.5 per cent. This is very close to the average deduction of 39.5 per cent found by the Australian study we discussed earlier, ${ }^{81}$ which looked both at court decisions and settlements, but was heavily weighted towards the latter. ${ }^{82}$

\footnotetext{
80 Pearson's chi-square test, $\mathrm{p}=0.679$.

81 See the text to 12 above.

82 Report of the National Committee of Inquiry on Compensation and Rebabilitation in Australia, n 10 above, vol 3, 97 (Table 14).
} 


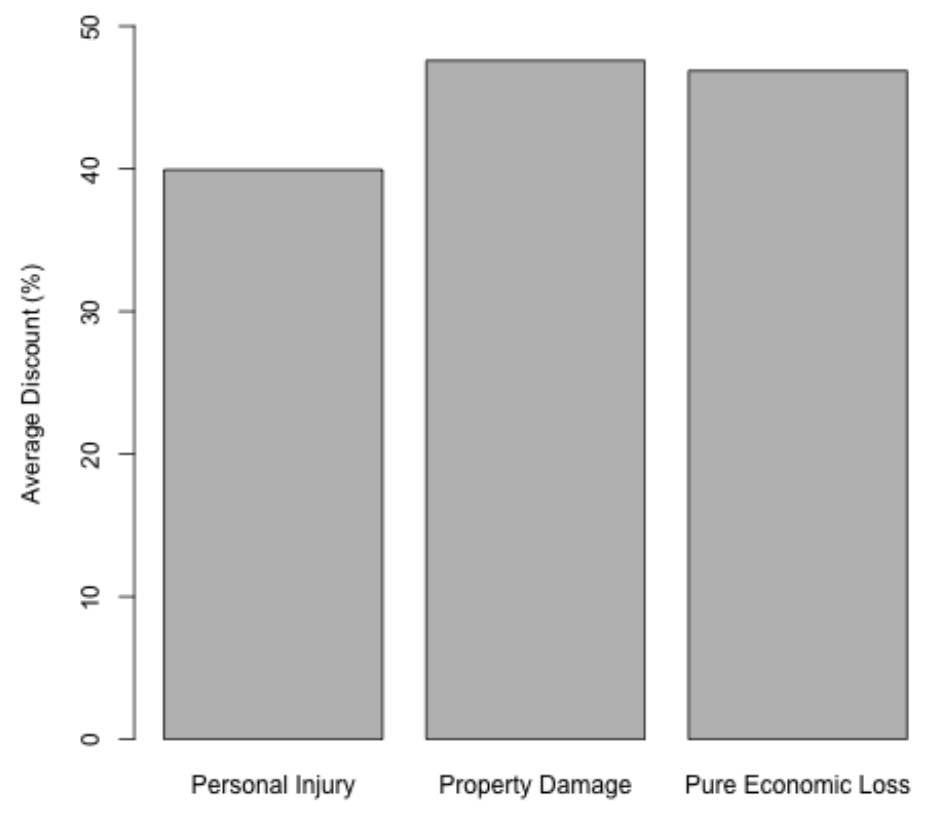

Figure 6 Average discount by damage type

Figure 6 shows the average discount by damage type. As the graph indicates, the average discounts in both property damage claims and pure economic loss claims (48 per cent in each case) were somewhat higher than the average discount in personal injury claims (40 per cent). In relation to pure economic loss claims, this disparity is likely to be bound up with the higher discounts found in professional negligence claims, ${ }^{83}$ as we have seen that most of the pure economic loss claims involved professional negligence (and vice versa). With respect to property damage claims, statistical analysis provided some evidence of an association between damage type and size of discount, ${ }^{84}$ but since there were only 9 property damage claims in which findings of contributory negligence were made, further research is required before it justifiably can be concluded that this disparity reflects a broader pattern. Further detail regarding the discounts made in respect of the three types of damage can be seen in a boxplot of discounts by damage type (Figure 7).

\footnotetext{
83 See Figure 8 and accompanying text, below.

${ }^{84}$ Linear regression analysis of the change in the average discount from personal injury claims to property damage claims (controlling for damage type, age and gender) returned a p-value of 0.076 .
} 


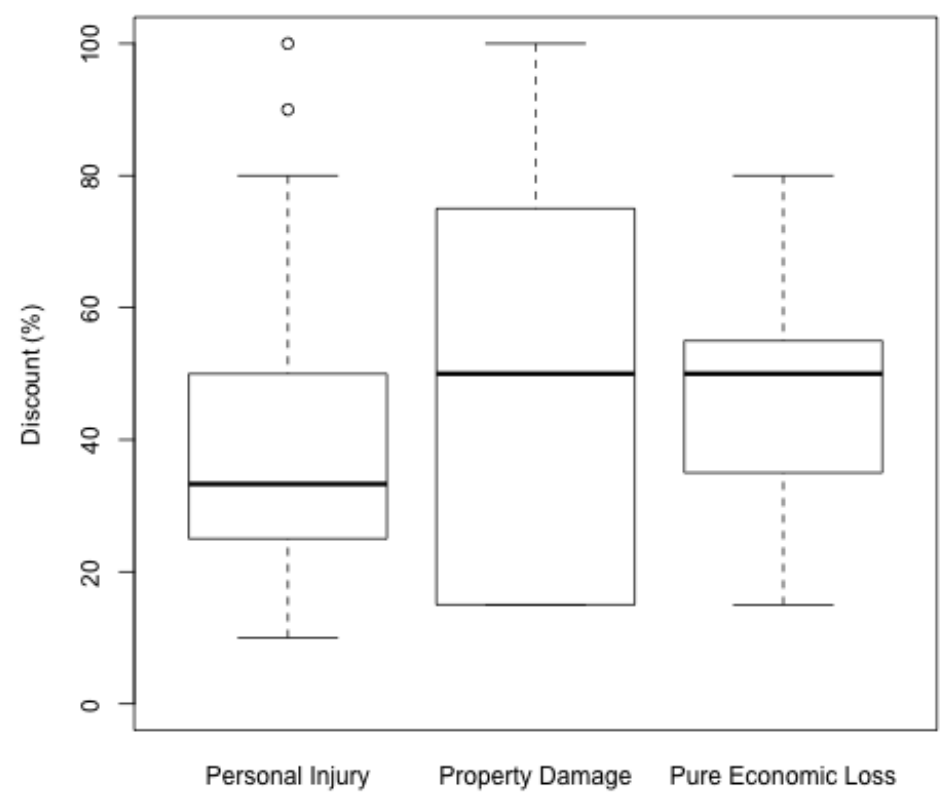

Figure 7 Discount by damage type ${ }^{85}$

Turning from type of damage to type of claim, the average discount by type of claim is shown in Figure 8. Several features of this graph are noteworthy. One is that the highest average discount (58 per cent) was found in professional negligence claims. Even though there were only 8 professional negligence claims in the sample where a discount was made, statistical analysis suggested that the disparity between the average discount in professional negligence claims and other types of claim (excluding occupiers' liability claims) was unlikely to be down to chance. $^{86}$ This suggests that while the courts are reluctant to find contributory negligence in professional negligence claims, ${ }^{87}$ when they do so the discount tends to be higher than in other types of claim.

A second noteworthy finding is that the average discount in employers' liability claims was relatively low (31 per cent). The disparity between this figure and the average discount in road accident claims (42 per cent) and occupiers' liability claims

\footnotetext{
85 The thick black line in the boxplot represents the median discount value, the box gives the first and third quartiles of the discount values, and the dotted lines extend out to 1.5 times the interquartile range (the range between the value at the first quartile and the third quartile). Outliers are drawn as dots.

${ }^{86}$ Two-sided t-tests of the differences between the average discounts in the various different types of claim gave relatively low p-values in the pairings of professional negligence claims with all other claim types, except for occupiers' liability claims (where the p-value was 0.402). For example, a paired t-test of professional negligence claims and road accident claims - the largest category of claim, and the one in which the average discount was closest to the average discount across all claims - returned a p-value of 0.057 . The results of the t-tests were broadly consistent with the results of Wilcoxon rank sum tests with continuity correction (eg, this test returned a p-value of 0.036 for the professional negligence/road accident pairing).

${ }^{87}$ See the text to $\mathrm{n} 76$ above.
} 
(51 per cent) was extremely unlikely to be down to chance, meaning that on the whole employees who are found guilty of contributory negligence are almost certainly treated more leniently than road users and those suing occupiers. ${ }^{88}$ This is an important finding, as the number of employers' liability claims is very high, ${ }^{89}$ and in our sample was second only to the number of road accident claims. ${ }^{90} \mathrm{We}$ should clarify what we mean by 'leniently' here (and when we use this and similar language below). Whenever damages are discounted for contributory negligence, the court does not consider the claimant's conduct in isolation. The claimant's responsibility for the damage is compared with the defendant's. Accordingly, a given act of contributory negligence by a claimant might attract different discounts depending on the relative significance to be attached to the defendant's negligence. The importance that a court attaches to a defendant's negligence depends, of course, on the entire factual matrix and dynamics of the claim. Our use of the word 'leniently' should be understood in this light. We mean only that, on average, claimants in employers' liability claims are treated more sympathetically than claimants in road accident claims or employers' liability claims simply in terms of the discount imposed (that is, in a raw mathematical sense). We recognise that a given discount in a specific claim, however low, may well not be 'lenient' in view of the facts in question. We acknowledge, too, that a certain discount in an individual claim may be more lenient (or harsher) than the same discount made in the context of another claim.

A third important finding concerns the relatively high average discount in occupiers' liability claims (51 per cent). Again, statistical analysis suggested that the disparity between the average discount in occupiers' liability claims and road accident claims was unlikely to be down to chance. ${ }^{11}$ (This figure of 51 per cent is for occupiers' liability claims globally. Most of the occupiers' liability claims in our study were brought by visitors (34 claims). The average discount in visitor claims was 49 per cent. Only 3 claims were brought by non-visitors, in all of which the claimant was found guilty of contributory negligence. The average discount in nonvisitor claims was 64 per cent. ${ }^{2}$ ) Our study therefore indicates that when it comes to discounting damages for contributory negligence, the courts may well in general

\footnotetext{
88 Two-sided t-tests of the differences between the average discounts in employers' liability claims and road accident and occupiers' liability claims respectively gave very low p-values $(<0.001$ in both instances). These results were consistent with the results of Wilcoxon rank sum tests with continuity correction (again, $\mathrm{p}<0.001$ in both claims). Linear regression analysis of the change in the average discount from road accident claims to employers' liability claims (controlling for damage type, age and gender) returned a p-value of 0.002 .

89 See the data reported in $\mathrm{n} 70$ above.

90 See Figure 2 above.

91 A two-sided t-test of the differences between the average discounts in occupiers' liability claims and road accident claims gave a p-value of 0.070 . This result was broadly consistent with the result of a Wilcoxon rank sum test with continuity correction $(p=0.059)$. Linear regression analysis of the change in the average discount from road accident claims to occupiers' liability claims (controlling for damage type, age and gender) returned a lower p-value of 0.035 .

92 A two-sided t-test of the difference between the average discounts in visitor and non-visitor claims returned a $\mathrm{p}$ value of 0.163 . A Wilcoxon rank sum test with continuity correction yielded a p-value of 0.236 .
} 
be harder on claimants in occupiers' liability claims, not only in comparison with claimants in employers' liability claims, but in comparison with claimants in road accident claims as well.

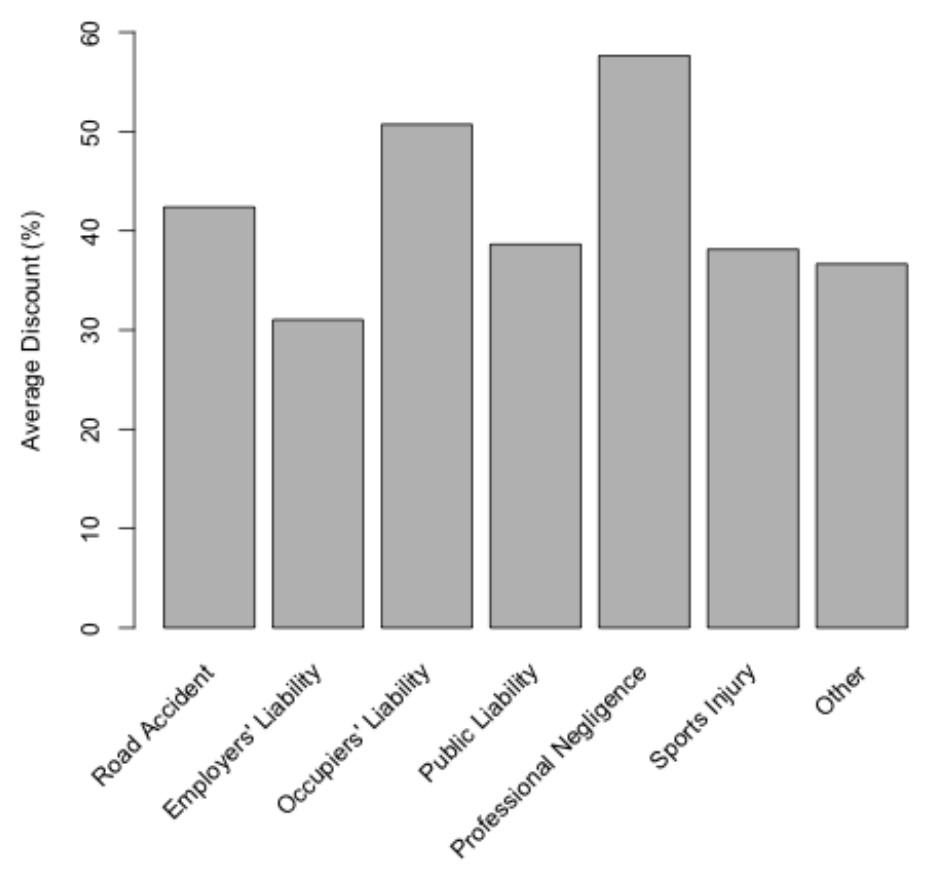

Figure 8 Average discount by type of claim

The average discount in the other four types of claim were all fairly close to the overall average discount of 40.5 per cent (road accidents, 42 per cent; public liability, 39 per cent; sports injury, 38 per cent; other, 37 per cent) and no significance can be attached to the minor disparities observable between the average discounts across these claim types. More detail on the interaction between discount and claim type is shown in Figure 9.

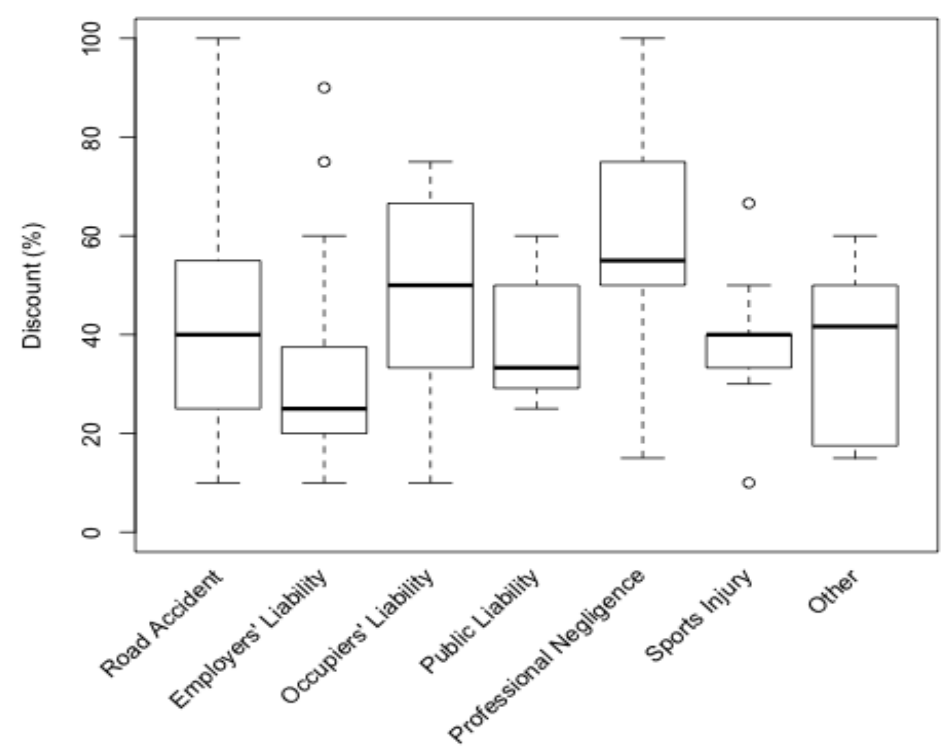


Figure 9 Discount by type of claim

Once again, no discernible trend emerges when we look at the average discount by year in personal injury claims (Figure 10). Statistical analysis strongly suggests that there was no association between average discount and year. ${ }^{93}$

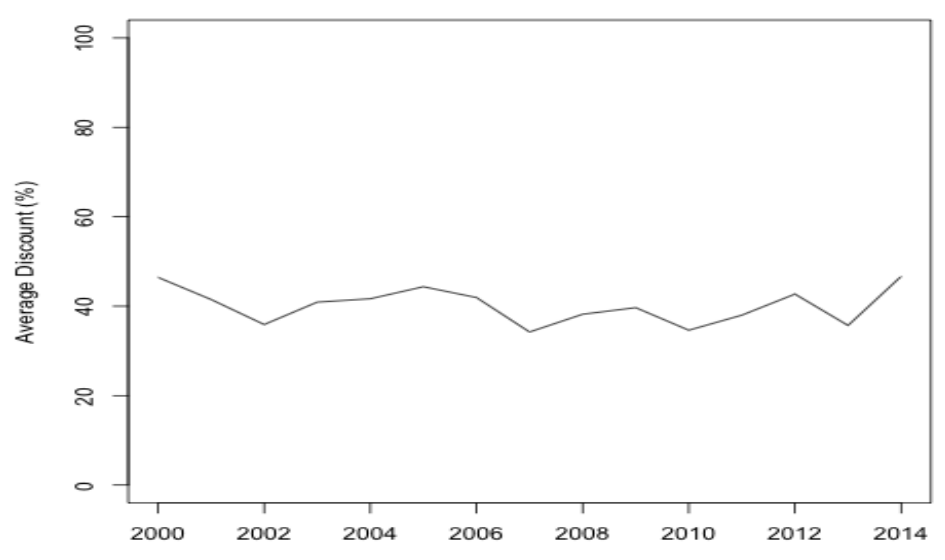

Figure 10 Average discount by year (personal injury claims)

Our study also reveals important facts about the range and frequency of discounts used by the courts. The lowest discount that we observed was 10 per cent (used in nine claims, all of them personal injury claims). In two claims (one involving personal injury and the other involving property damage) a discount of 100 per cent was made. ${ }^{94}$ By far the most popular discount was 50 per cent (43 claims), followed by 25 per cent and 33.3 per cent ( 27 claims each). Table 1 sets out the most common discounts. Other discounts used were: 12.5 per cent (1 claim); 35 per cent $(2$ claims); 45 per cent $(1$ claim); 55 per cent $(2$ claims); 65 per cent (1 claim); 70 per cent ( 2 claims); 90 per cent (1 claim); and 100 per cent ( 2 claims). The most popular discounts are of course fractions that are the most frequently used in everyday life, namely one-half, one-third and one-quarter. ${ }^{95}$

\footnotetext{
93 An analysis of variance comparing the average discount for each year produced a very high $\mathrm{p}$-value $(\mathrm{p}=0.841)$.

${ }^{4}$ Marshall v Lincolnshire Roadcar Co (Lincoln CC, 3 February 2000); Six Continents Retail Ltd v Carford Catering Ltd [2003] EWCA Civ 1790. We address the appropriateness of 100 per cent discounts later: see the text accompanying n 135 below.

95 cf Jackson n 25 above at [28], where Lord Reed said that apportionment for contributory negligence is 'inevitably a somewhat rough and ready exercise', and that this is a 'feature reflected in the judicial preference for round figures'. See, similarly, R. Stevens, 'Contributory Fault: Analogue or Digital?' in A. Dyson et al (eds), Defences in Tort (Oxford: Hart Publishing, 2015) 259 (noting that when deciding on discounts for contributory negligence, 'judges seldom select finely tuned figures, $73 / 27$ for example').
} 


\begin{tabular}{|c|c|}
\hline $\begin{array}{c}\text { Number of } \\
\text { claims }\end{array}$ & Discount (\%) \\
\hline 43 & 50 \\
\hline 27 & 25 \\
\hline 27 & 33.3 \\
\hline 22 & 20 \\
\hline 15 & 15 \\
\hline 15 & 40 \\
\hline 13 & 75 \\
\hline 12 & 60 \\
\hline 11 & 66.6 \\
\hline 9 & 10 \\
\hline 9 & 30 \\
\hline 5 & 80 \\
\hline
\end{tabular}

Table 1 Most frequently used discounts

Finally, a graph of the number of claims by discount range (Figure 11) gives a clearer indication of the distribution of discounts, with a marked preference for discounts between 10 per cent and 50 per cent, and a pronounced falling off in the number of claims beyond the 50 per cent mark (in only two of the 45 claims in the 50-59 per cent range was the discount greater than 50 per cent - in both instances, 55 per cent). The relatively low number of claims in the $40-49$ per cent range ( 16 claims, in all but one of which the discount was 40 per cent) can probably be explained by the fact that none of the fractions most commonly used in daily life (one-half, one-third, one-quarter, two-thirds etc) falls within this range.

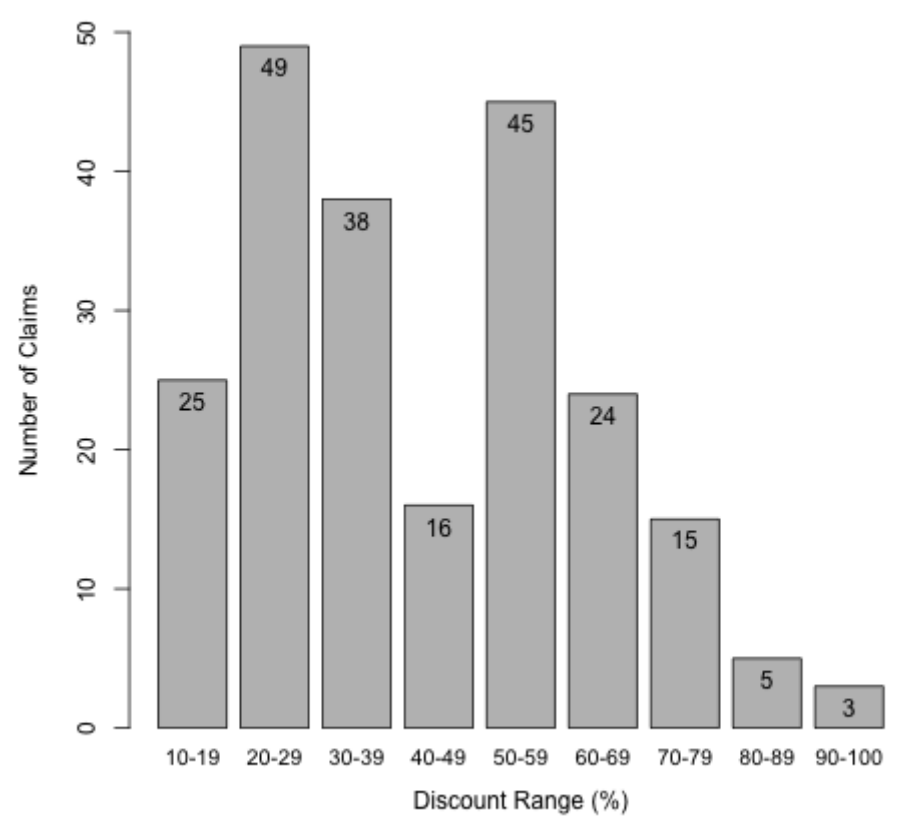

Figure 11 Number of claims by discount range 


\section{Contributory negligence and claimant age}

Of the 368 claims in our sample, 69 were brought by non-human claimants or claimants whose age was left too unclear by the court for it to be determined whether they were children or adults. Of the remaining 299 claims, 39 (13 per cent) were brought by children and 260 (87 per cent) were brought by adults. We were able to discern the age of the claimant with precision in 163 claims. The youngest claimant was aged $6,{ }^{96}$ while the oldest was $79 .{ }^{97}$ The distribution of these 163 claims by claimant age range is shown in Figure 12 .

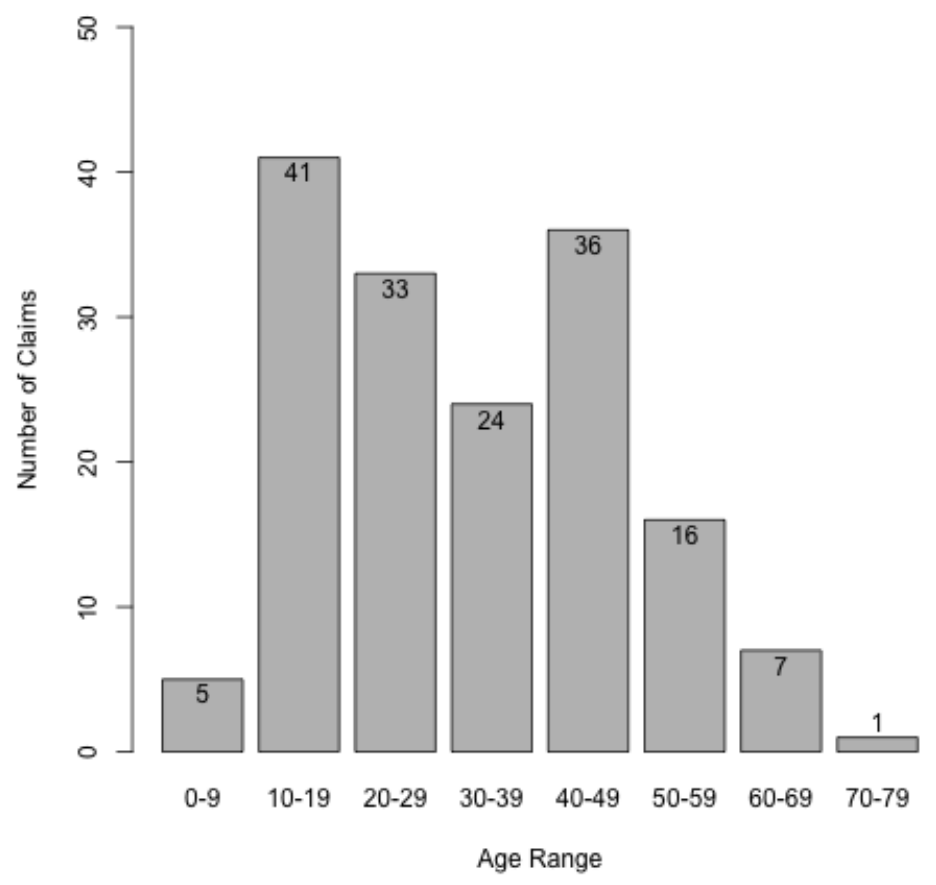

Figure 12 Number of claims by claimant age range

As can be seen from this graph, the claimant age range with the largest number of claims is $10-19$ years ( 25 per cent of all claims), followed by $40-49$ years ( 22 per cent) and then 20-29 years (20 per cent). There are relatively few claims in which the claimant was aged 50 or over (15 per cent). When looking at these figures, it should be borne in mind that it seems likely that the incidence of personal injury claims generally (and road accident claims specifically) is relatively low in respect of young children and the elderly. ${ }^{98}$ It should also be borne in mind that there were a large number of claims in the sample (136) where it was clear that the claimant was

\footnotetext{
${ }^{96}$ Boardman v Ministry of Defence (High Court, 12 November 2010).

${ }_{97}^{97}$ Palfrey v WM Morrisons Supermarkets Plc [2012] EWCA Civ 1917.

${ }^{98}$ In the Australian survey of personal injury claims discussed earlier (see the text to $\mathrm{n} 11$ above), the proportions of claims by children under 14 and by elderly persons aged over 65 were much lower than the proportions of the general population in these age groups: Report of the National Committee of Inquiry on Compensation and Rehabilitation in Australia, n 11 above, vol 3, 91-92 (Tables 1 and 2).
} 
an adult but where we could not discern the age of the claimant more precisely. These claims are not included in Figure 12, which therefore over-represents the proportion of claimants in the sample who were under 18 (as in all the claims where it was possible to discern that the claimant was a child it was also possible to discern the claimant's age more precisely). Furthermore, there were a considerable number of additional claims in the sample where it was unclear whether a human claimant was a child or an adult, and we might reasonably suppose that most if not all of these claims in fact involved adults, since it seems unlikely that a judge would fail to mention the age of a claimant who was under 18 (not least because this might affect the analysis of the contributory negligence issue). ${ }^{99}$ It is highly likely, therefore, that if we had age data for all of the human claimants in our sample, the number of claims in all the age ranges from and including 20-29 years and above would be higher, and in some instances substantially so.

Turning to the relationship between age and the success rate of the plea of contributory negligence, the plea succeeded in 72 per cent of claims where the claimant was a child, and 62 per cent of claims where the claimant was an adult. This striking result suggests that, if anything, courts are more likely to find contributory negligence against a child claimant, although statistical analysis showed that this disparity might well be down to chance. ${ }^{100}$ The youngest claimant found guilty of contributory negligence was aged $7 ;^{101}$ the oldest was $79 .{ }^{102}$

\footnotetext{
99 This reflects the fact that incompleteness in the factual data provided by a judicial opinion arises 'because judges' factual presentations are meant only to explain as much of the case as is necessary to justify the outcome': Hall and Wright, n 42 above, 95-96.

100 Pearson's chi-square test with Yates's continuity correction, $\mathrm{p}=0.290$. Logistic regression (controlling for claim type, damage type and gender) returned a p-value of 0.205 .

101 N (a child) v Newham LBC [2007] CLY 2931 (the claimant punched a pane of glass while at school).

102 Palfrey n 97 above.
} 
A breakdown of the success rate of the plea of contributory negligence by age range can be seen in Figure 13. As this graph shows, the success rate was lowest

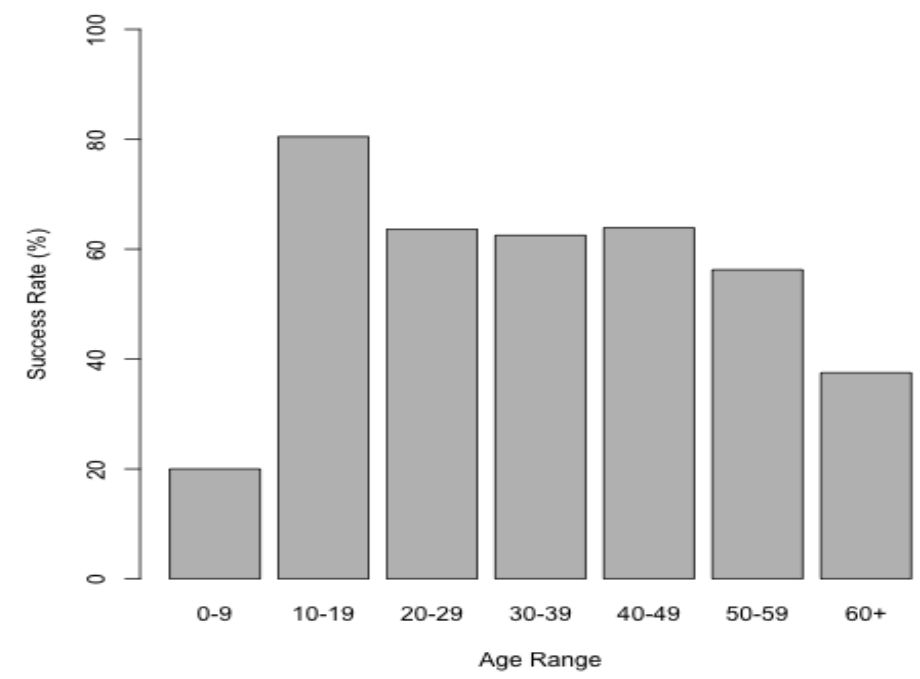

for claimants in the $0-9$ and $60+$ age ranges $(20$ per cent and 38 per cent respectively), but the small number of claims in these age ranges means that great significance should not be attached to these results. The age range where the plea of contributory negligence was most likely to succeed in our sample was 10-19 (success rate of 81 per cent). This figure is considerably higher than the success rate across all claims of 60 per cent, and allows us to finesse our earlier proposition about success rate and children to the claim that the plea of contributory negligence was substantially more likely to succeed where the claimant was aged 10-19 years. Furthermore, statistical analysis suggests that this is unlikely to be down to chance. ${ }^{103}$ Success rates in the remaining four age ranges were more tightly clustered, as follows: 20-29 years, 64 per cent; 30-39 years, 63 per cent; 4049 years, 64 per cent; and 50-59 years, 56 per cent.

Figure 13 Success rate of plea by claimant age range

Turning to the relationship between discount and age, the average discount for children was 43 per cent, and the average discount for adults was 39 per cent. In other words, not only is a finding of contributory negligence more likely where the claimant is a child, but in such claims it is probable that the discount will be higher as well. However, statistical analysis shows that this disparity is likely to be

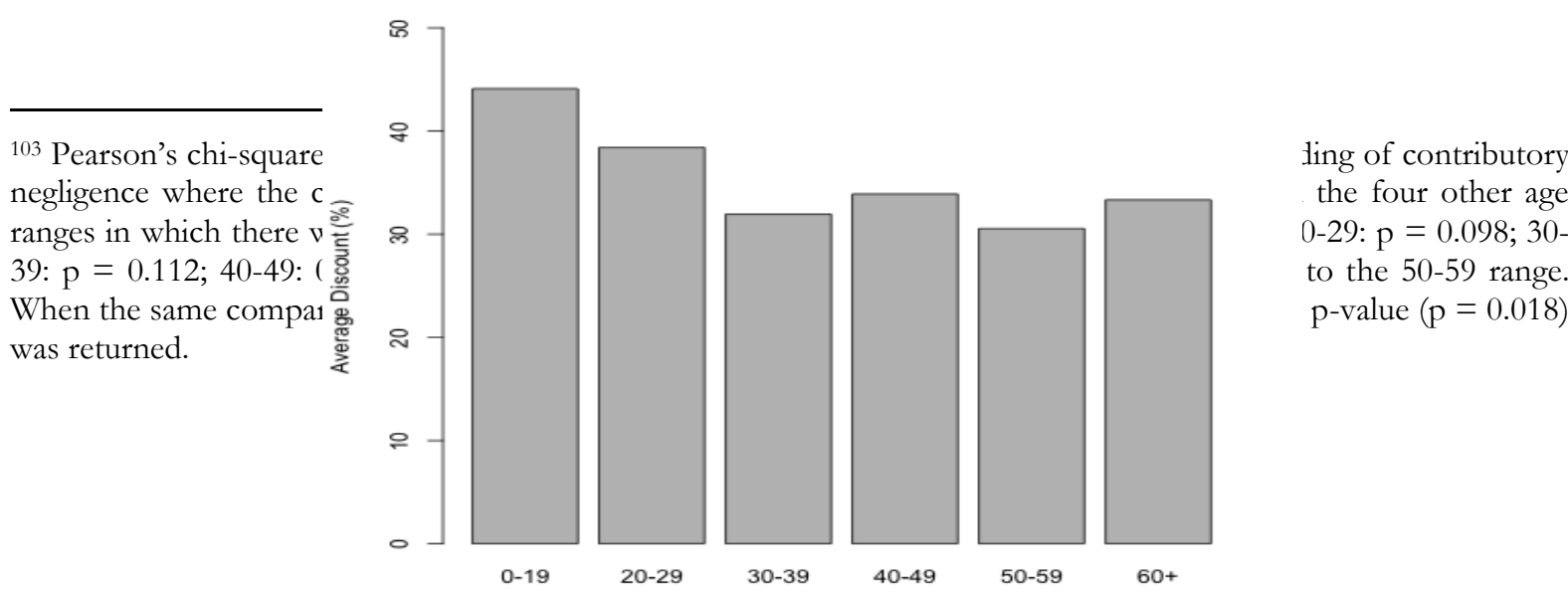


attributable to other factors, such as the prevalence of child claimants in claim types where higher discounts tend to be made. ${ }^{104}$

Figure 14 Average discount by claimant age range

Figure 14 shows the average discount by claimant age range. No strong trend is discernible, although the highest average discounts are found in the two youngest age ranges (0-19 years, 44 per cent; $20-29$ years, 38 per cent). The average discounts in the other four age ranges are very similar (30-39 years, 32 per cent; 4049 years, 34 per cent; 50-59 years, 31 per cent; and 60+ years, 33 per cent). It should be noted that although the average discounts for claimants in the two youngest age ranges look high, neither is far from the average discount across all claims in the sample ( 40.5 per cent). It follows that when compared to the average discount across all claims, it is the average discounts in the other age ranges that are marginally out of line. A possible explanation for this is that the age of an adult claimant is more likely to be discernible in types of claim where a lower discount tends to be made, in particular employers' liability claims (where the average discount is a mere 31 per cent). ${ }^{105}$ All in all, it seems that the size of the discount is probably more strongly associated with type of claim than with age.

\section{Contributory negligence and claimant gender}

Of the 368 claims in our sample there were 39 where the claim was brought by a non-human claimant or where it was not possible to discern the claimant's gender. Of the 329 claims remaining, 229 (70 per cent) were brought by men, and 100 (30 per cent) were brought by women. Since all but 14 of these claims were brought for personal injury, this disparity may reflect the fact that men bring more personal injury claims than women, but although men are undoubtedly more likely to be injured in circumstances where compensation may be payable, such as on the roads, ${ }^{106}$ it is unclear whether they bring more personal injury claims as a result. ${ }^{107}$

\footnotetext{
104 A two-sided t-test of the difference between the average discounts in child claimant and adult claimant claims gave a p-value of 0.246 . This result was broadly consistent with the result of a Wilcoxon rank sum test with continuity correction $(p=0.205)$. However, linear regression analysis (controlling for case type, damage type and gender) returned a much higher p-value of 0.748 .

105 See Figure 8 and accompanying text, above.

106 For example, 70 per cent of those reported as killed or seriously injured in road accidents in the UK (excluding Northern Ireland) in the period 2005-2009 were men: https://www.gov.uk/government/publications/reportedroad-casualties-great-britain-annual-report-2013 (accessed 14 January 2016). Similarly, the Pearson Commission, n 10 above, vol 2, 9 (Table 2) estimated that at the time of its report men suffered work injuries over six times more often than women, even though only 50 per cent more men were working at that time than women (ibid, para 334), although under modern employment conditions, the gender gap is likely to be much narrower.

107 There appear to be no concrete data on the relationship between gender and personal injury claims in the UK at the present time. In the early 1990s, men accounted for 80 per cent of respondents in the three lower settlement bands in the Law Commission's survey of compensated victims of personal injury, and 65 per cent of respondents in the highest settlement band: Law Commission, n 16 above, para 2.4. However, more recent figures from Ireland indicate that any gender gap in terms of claiming may now be much reduced, or even non-existent. According to the Irish Personal Injuries Assessment Board, in 201251 per cent of motor liability awards and 30 per cent of workplace liability awards for personal injury were made to women (Annual Report of the Personal Injuries Assessment Board 2013
} 
In any case, there is a distinct possibility that this disparity is attributable (at least in part) to the fact that women are generally more risk-averse than men, ${ }^{108}$ and so less likely to act in such a way as to expose them to a plausible plea of contributory fault.

With respect to the relationship between success rate of the plea of contributory negligence and gender, this was higher for male claimants than for female claimants (66 per cent and 57 per cent, respectively). Statistical analysis provides only weak evidence that this difference exists in the wider population of claims. ${ }^{109}$ Again, any more general disparity between women and men in this regard might be attributable to women being more risk-averse, and so more likely to be able successfully to rebut a plea of contributory fault. As for the relationship between size of discount and claimant gender, the average discount in claims involving male claimants was 39 per cent, and the average discount in claims involving female claimants was 42 per cent. Further detail on the relationship between discount and gender can be gleaned from Figure 15.

(2014) 18-19), while in 201072 per cent of public liability awards for personal injury were made to women (Annual Report of the Personal Injuries Assessment Board 2010 (2011) section 4).

${ }^{108}$ The literature in this regard is on a vast scale. A widely-cited study of over 150 published articles regarding gender differences in the propensity to run risks concluded that 'our results clearly support the idea that male participants are more likely to take risks than female participants': J.P. Byrnes, D.C. Miller and W.D. Schafer, 'Gender Differences in Risk Taking: A Meta-analysis' (1999) 125 Psychological Bulletin 367, 377. For more recent analyses to similar effect, see J.J. Rolison et al, 'Risk-Taking Differences Across the Adult Life Span: A Question of Age and Domain' [2013] Journals of Gerontology, Series B, 5; C.R. Harris and M. Jenkins, 'Gender Differences in Risk Assessment: Why Do Women Take Fewer Risks than Men? (2006) 1 Judgment and Decision Making 48.

109 Pearson's chi-square test, $\mathrm{p}=0.142$. Logistic regression analysis (controlling for claim type, damage type and age) returned a higher $\mathrm{p}$-value of 0.270 . 


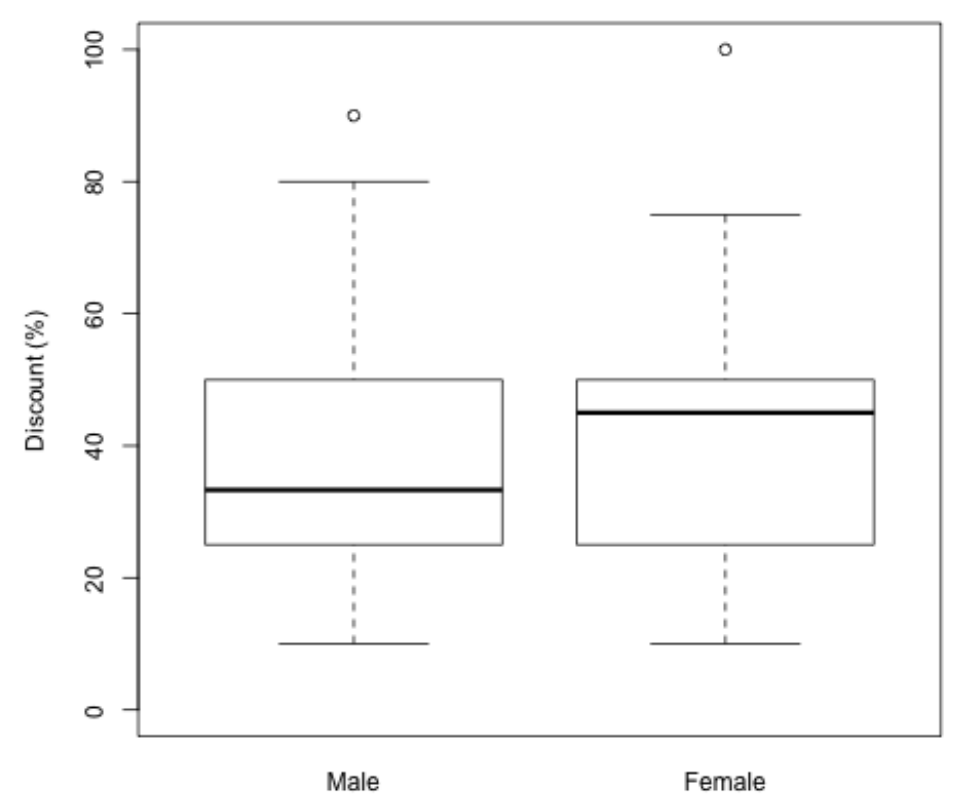

Figure 15 Discount by claimant gender

Statistical analysis of these figures shows that there is a decent probability that the disparity between the average discount for male and female claimants is due to chance. ${ }^{110}$ Furthermore, a possible explanation for the lower average discount for male claimants is the fact that men are over-represented in employers' liability claims ${ }^{111}$ since we have seen that this is the type of claim in which the average discount is the lowest. ${ }^{112}$

\section{DISCUSSION}

In this section of the article, we highlight what we consider to be the most important findings of our study and discuss those findings in the light of the relevant academic literature.

\section{Overall success rate and average discount}

\footnotetext{
110 Two-sided t-test, $\mathrm{p}=0.353$. This result was broadly consistent with the result of a Wilcoxon rank sum test with continuity correction $(\mathrm{p}=0.327)$.

11121 per cent of the claims in which female claimants were found guilty of contributory negligence were employers' liability claims; the equivalent figure for male claimants was 29 per cent. This hypothesis is supported by the fact that linear regression analysis of the change in average discount from male claimant claims to female claimant claims (controlling for claim type, damage type and age) returned a higher $\mathrm{p}$-value of 0.589

112 See Figure 8 and accompanying text, above.
} 
The plea of contributory negligence succeeded in 60 per cent of the claims in our sample. In claims where a finding of contributory negligence was made, the average discount was 40.5 per cent. Given that it appears that contributory negligence is pleaded very frequently, ${ }^{113}$ these findings underscore the practical importance of the contributory negligence doctrine.

\section{Employers' liability}

The finding of our study that is perhaps of greatest practical importance is that in our sample damages were discounted for contributory negligence by a significantly smaller amount in employers' liability claims than in road accident and occupiers' liability claims. This finding presumably reflects a general tendency on the part of courts to treat claimants in employers' liability claims especially sympathetically. However, it is noticeable that despite judges frequently stating that courts should be reluctant to find employees guilty of contributory negligence, particularly where an employee sues an employer for a breach of a statutory duty imposed to protect employees, ${ }^{114}$ we found no evidence in our study of such leniency. Leniency was manifested only at the apportionment stage.

\section{Occupiers' liability}

Another important finding of our study was that the average discount in occupiers' liability claims was relatively high, when compared to other claim types that often involve personal injury claims, such as road accident and employers' liability claims. This may be attributable to the fact that many of the claimants in such claims behave in a particularly foolhardy manner. (We considered the possibility that this result might be explicable on the basis that many of the claimants in occupiers' liability claims might be trespassers. However, this explanation is untenable in the light of the fact that only 3 claims out of a total of 37 occupiers' liability claims in our sample were brought by non-visitors).

\section{Professional negligence}

\footnotetext{
113 See the text accompanying nn 1-2 above and the sources cited in those notes.

${ }^{114}$ See, eg, Caswell v Powell Duffryn Associated Collieries Ltd [1940] AC 152, 179-180 (Lord Wright); Hutchinson v London and North Eastern Rly Co [1942] 1 KB 481, 488 (Goddard LJ); Hopwood v Rolls-Royce Ltd (1947) 176 LT 514, 520 (Lord Greene MR); Staveley Iron \& Chemical Co Ltd v Jones [1956] AC 627, 648 (Lord Tucker); Quintas v National Smelting Co Ltd [1961] 1 WLR 401, 408 (Sellers LJ); Proctor v City Facilities Management Ltd [2012] NIQB 99 [22] (Horner J). The foregoing are all cases in which explicit statements were made to the effect that judges should be reticent to find employees guilty of contributory negligence. There are countless cases in which this understanding is implicitly endorsed. Such cases include Toole v Bolton MBC [2002] EWCA Civ 588, especially at [13] (Buxton LJ); and Nixon v Chanceoption Developments Ltd [2002] EWCA 558, especially at [13]-[15] (Sedley LJ). For discussion, see D. Bennett (ed), Munkman on Employer's Liability (London: LexisNexis, 16th ed, 2013) paras 6.47-6.59; K. Oliphant (ed), The Law of Tort (London: LexisNexis Butterworths, 3rd ed, 2015) para 15.52.
} 
Intriguing data emerge from our study concerning the operation of the contributory negligence doctrine in the professional negligence context. Setting aside medical negligence claims - where our study provides further evidence that pleas of contributory negligence are most unusual ${ }^{115}$ - three conclusions can be drawn: (1) contributory negligence is frequently pleaded in professional negligence litigation (11 per cent of the claims in our sample were professional negligence claims); (2) pleas of contributory negligence are considerably less likely to succeed in professional negligence claims than in other types of claim; and (3) when claimants are found guilty of contributory negligence in professional negligence claims, the average discount is considerably higher than in other types of claim. In the light of (2), (1) is perhaps surprising, and it is possible that the lawyers acting for defendants in professional negligence claims are not aware of how unlikely a plea of professional negligence is to succeed in that context. On the other hand, it is possible that these lawyers are aware of the low success rate of the plea, but also of the relatively high discounts that judges impose when they make a finding of contributory negligence in this context, and that this latter consideration proves decisive.

The second of these conclusions is consistent with the commonly expressed view that it is difficult for a defendant in a professional negligence claim to make an allegation of contributory negligence stick. ${ }^{116}$ There are obvious reasons why a professional will often face 'grave difficulty'117 in establishing contributory negligence, including the fact that the professional will usually have greater expertise than the client in the relevant field, that the power relationship between professional and client is often asymmetrical, and that it will often be reasonable for the client to follow professional advice. These explanations are consistent with the differential treatment of human and corporate claimants in this context (since it might plausibly be supposed that corporate claimants are generally more capable of assessing the merits of professional advice than human claimants). In our sample only 15 per cent of human claimants were found guilty of contributory negligence in professional negligence claims while the equivalent figure for corporate claimants was 36 per cent. However, the relevant sample size is small, and statistical analysis showed that this disparity could well be down to chance. ${ }^{118}$ On the other hand, the average discount imposed on human and corporate defendants was almost identical (both 58 per cent, when rounded up), although the average discount figure for human claimants is of limited significant, since in our sample

\footnotetext{
115 See the discussion in $\mathrm{n} 73$ above.

116 See, eg, J. Powell et al, Jackson \& Powell on Professional Liability (London: Sweet \& Maxwell, 7th ed, 2012) para 5-146 ('[i]n the context of professional negligence a successful plea of contributory negligence by the defendant is less common than in other areas of negligence').

117 D.W. Marks, 'Professional Negligence: Contribution and Contributory Negligence' (1988-1989) 15 U Queensland LJ 209, 226-227.

118 A Pearson's chi-square test of the difference in the frequency with which contributory negligence was found as between human and corporate claimants in professional negligence cases yielded a p-value of 0.336 .
} 
only two human claimants were found guilty of contributory negligence in a professional negligence claim.

In the light of these considerations, it is interesting to observe that while pleas of contributory negligence are less likely to succeed in professional negligence claims, when they do succeed the average discount is considerably higher than in all other types of claim, except for occupiers' liability claims. Quite why this inverse relationship exists is unclear. One plausible explanation is that claimants need to do something particularly unreasonable in order to be found guilty of contributory negligence in a professional negligence claim, an inference that one could draw from the low success rate of pleas of contributory negligence in this context. If this is correct, then judges might conclude that claimants who have been found guilty of contributory negligence in professional negligence claims deserve to have their damages discounted by a sizeable amount.

\section{Claimant age}

Our study contains several interesting findings about the relationship between contributory negligence and claimant age. One is that there was only one instance where a claimant under the age of 10 was found guilty of contributory negligence, ${ }^{119}$ although contributory negligence was pleaded against five children under 10 , one as young as $6 .{ }^{120}$ Although the number of claims involving children under 10 in our sample is small, our study suggests that children younger than 10 are unlikely to be found guilty of contributory negligence. This conclusion - which tallies nicely with the fact that 10 is the age of criminal responsibility ${ }^{121}$ - is broadly consistent with Lord Denning MR's declaration that '[a] very young child cannot be guilty of contributory negligence'. ${ }^{122}$ On the other hand, five out of the six claimants in our sample aged 10 or 11 were found guilty of contributory negligence, and four of these five claimants were injured in road accidents. In 1978 the Pearson Commission stated that the courts were increasingly reluctant to reduce damages awarded to young children for motor vehicle injury on the grounds of the child's contributory negligence', and argued that this development

\footnotetext{
119 In AB v Main [2015] EWHC 3183 (QB), judgment in which was handed down after our study period, a boy who was aged eight years and ten months at the time of the accident was found guilty of contributory negligence in a motor vehicle claim. A 20 per cent discount was imposed.

${ }^{120}$ See generally on children and contributory negligence, Barnes, $\mathrm{n} 7$ above.

121 Children and Young Persons Act 1933, s 50 (as amended by the Children and Young Persons Act 1963, which raised the age from eight).

${ }^{122}$ Gough n 31 above, 1390. See also Gardner v Grace (1858) 1 F \& F 359, 359; 175 ER 763, 763 (Channell B) ('The doctrine of contributory negligence does not apply to an infant of tender age'). However, it has been said that in this context children of 'tender years' means those under four (Barnes, n 7 above, 205), and the Scottish courts have found children aged between four and six guilty of contributory negligence: see Cass v Edinburgh \& District Tramways Co Ltd 1909 SC 1068 (four); McKinnell v White 1971 SLT 61 (five); Banner's Tutor v Kennedy's Trustees 1978 SLT (notes) 83 (five); Harvey v Cairns 1989 SLT 107 (six). According to Glanville Williams (writing in 1951), some courts in Canada and the US had held that as a matter of law no child under seven could be guilty of contributory fault: Williams, n 28 above, 355.
} 
should be given statutory force by a provision barring reliance on contributory negligence in motor vehicle injury claims where the claimant was under 12 years of age at the time of the accident. ${ }^{123}$ Only recently, a distinguished scholar claimed that such an enactment 'would make very little difference to the practical position at present'. ${ }^{124}$ Our study suggests otherwise.

Perhaps our most important finding on the age front, however, was that the success rate of the plea of contributory negligence was considerably higher for claimants in the 10-19 years age range than for claimants in any other age range. To reiterate, 81 per cent of claimants aged between 10 and 19 were found guilty of contributory negligence, a figure more than 20 per cent higher than the average success rate across the whole sample. Furthermore, the average discount in the 0 19 age range was also the highest, at 44 per cent. 83 per cent of the claimants in the 10-19 age range were children, and we have also seen that the plea of contributory negligence was successful in 72 per cent of claims where the claimant was a child, and 62 per cent of claims where the claimant was an adult, and that the average discount was higher where the claimant was a child (43 per cent, as against 39 per cent for adults).

The foregoing findings cast significant doubt on the accuracy of the commonly expressed perception that courts treat children more leniently than adults when it comes to the application of the contributory negligence doctrine. According to one leading textbook, for example, 'The courts have been singularly lenient to children both in terms of finding them guilty of contributory negligence and in apportioning damages. ${ }^{125}$ Similar remarks have been made elsewhere. ${ }^{126}$ Our study suggests that in fact pleas of contributory negligence are more likely to succeed against children aged 10 or over than against adults, despite the fact that an agerelative standard of care is applied to child claimants. ${ }^{127}$

This seems to us to be both an important and a surprising finding. One possible explanation for it might be that defendants are reluctant to plead contributory negligence against children, and so only do so in the most obvious instances of claimant fault. There are several reasons why defendants might be reluctant to plead contributory negligence against children, including the possibility of adverse

\footnotetext{
123 Pearson Commission, n 10 above, vol 1, para 1077.

${ }^{124}$ Cane, $\mathrm{n} 4$ above, 53.

125 C. Sappideen and P. Vines (eds), Fleming's The Law of Torts (Sydney: Thomson Reuters Professional (Australia) Ltd, 10th ed, 2011) 330.

126 The author of Street on Torts claims that it is ordinarily more difficult for the defendant to establish contributory negligence if the claimant is an infant than where he is an adult' and that when it comes to apportionment 'infant claimants are treated very leniently because of their vulnerability', with decisions on apportionment 'often made very much in their favour': C. Witting, Street on Torts (Oxford: OUP, 10th ed, 2015) 187, 195. (Note, however, that it is not entirely clear what the author means by the word 'infant' here, and, in particular, whether the word is being used in a legal sense, to refer to persons under the age of 18 years, or in a colloquial sense, to refer to young children).

${ }^{127}$ See $n 31$ above.
} 
publicity, sympathy on the part of claims handlers, and the risk of alienating a judge sympathetic to an injured child. However, we think such an explanation unlikely. After all, a defendant has little reason not to plead contributory negligence if there is a chance that the plea will be successful given the significant effect that the doctrine can have on the extent of the claimant's recovery, and in our sample there were a substantial number of claims involving claimants aged between 10 and 19 years old. Two other possible explanations present themselves. One is that in practice judges are not, contrary to authority, applying an age-relative standard of care to child claimants, but holding them to an adult standard. And the other is that children (or perhaps more specifically teenagers) are less risk averse than people in other age groups, and so tend to take less care of their own safety. There is considerable evidence to support this final possibility: according to one commentator, neuroscience research demonstrates that 'adolescents as a class of person possess an unavoidable predisposition to engage in physical risk-taking that increases both their exposure to harm and the likelihood of its occurrence'. ${ }^{128}$

Finally, it is worth reiterating that our study suggests that claimants aged 50 or over are less likely to be found guilty of contributory negligence (the success rate of the plea of contributory negligence for claimants in this age range was 50 per cent, compared with a success rate across all the claims in the sample of 60 per cent). One possible explanation for the relative infrequency of findings of contributory negligence in claims involving elderly claimants is that as people age they become more risk averse, and so take fewer chances with their own safety. ${ }^{129}$ Another potential explanation is that judges are simply more lenient towards elderly claimants when it comes to contributory negligence, as has indeed been suggested by commentators. ${ }^{130}$

\section{Claimant gender}

Turning to gender, it is interesting to note that in our sample pleas of contributory negligence were more frequently successful against male claimants (66 per cent) than against female claimants ( 57 per cent), though statistical analysis shows that there is a real possibility that this disparity is down to chance. Conversely, the average discount was higher in claims involving female claimants than in claims involving male claimants, although the difference was small and, statistically speaking, justifiably attributable to chance. It is also important to recall that in our

\footnotetext{
128 D. Thorpe, 'Adolescent Negligence, “Obvious Risk” and Recent Developments in Neuroscience' (2014) 21 Torts LJ 195, 219. See also Rolison et al, n 108 above, 6 (reporting that risk-taking attitudes in the recreational domain reduce sharply from age 18 upwards); L. Steinberg, 'Risk Taking in Adolescence: New Perspectives from Brain and Behavioral Science' (2007) 16 Current Directions in Psychological Science 55 (noting that 'statistics on automobile crashes, binge drinking, contraceptive use, and crime' reveal that '[a]dolescents and college-age individuals take more risks than children or adults do'.

${ }^{129}$ Rolinson et al, n 128 above, 7 (Figure 1 (recreational domain)).

${ }^{130}$ See, eg, Cane, n 4 above, 53.
} 
sample male claimants (70 per cent) far outnumbered female claimants (30 per cent), although since it appears that there are no data on the overall number of personal injury claims brought by men and women respectively in the study period, it is impossible to know to what extent this evidences a greater propensity for defendants to plead contributory negligence against male claimants.

Mayo Moran's gender-centred analysis of the operation of the contributory negligence doctrine in claims involving children led her to conclude that:

[A]ssumptions about what kind of behaviour is natural for girls as opposed to boys effectively results in different standards for contributory negligence. The normal boy, it seems, seeks risks and is therefore not chastised for so doing; in contrast, the normal girl seeks safety and avoids risks and is held to that standard. The consequence is that the range of situations in which the playing girl will be able to recover damages from a tortfeasor will be far more limited than the situations in which the boy will be permitted to recover. ${ }^{131}$

We found no evidence to support this claim in our study, where the success rate of the plea of contributory negligence was almost identical for female claimants aged under 18 (69 per cent ${ }^{132}$ ) and male claimants aged under 18 (70 per cent $\left.{ }^{133}\right)$. Furthermore, the average discount for male children was 64 per cent, while for female children the average discount was 44 per cent. Nor does our study provide any evidence that different standards for contributory negligence are applied to female and male claimants more generally.

\section{The range of discounts imposed}

Another interesting point that emerges from our study concerns the range of discounts. The lowest discount in our sample was 10 per cent. This is consistent with the observation made in the academic literature that holdings that the claimant's share of responsibility is less than 10 per cent are 'unusual'. ${ }^{134}$ At the

\footnotetext{
${ }_{131}$ M. Moran, Rethinking the Reasonable Person: An Egalitarian Reconstruction of the Objective Standard (Oxford: OUP, 2003) 128-129. See also ibid, 153-154 ('Conceptions of what is normal and natural mean that the girl must inhabit the public world with more caution').

1329 out of 13 claims.

13319 out of 27 claims.

${ }^{134}$ See, eg, J. Goudkamp, 'Rethinking Contributory Negligence' in E. Chamberlain et al (eds), Challenging Orthodoxy in Tort Law (Oxford: Hart Publishing, 2013) 350. See also Clerk \& Lindsell on Torts (London: Sweet \& Maxwell, 21 st ed, 2014) para 3-87 ('where one of the parties is less than 10 per cent responsible no apportionment should normally be made'); and Barnes, $\mathrm{n} 7$ above, 200n (remarking that it is standard practice not to make a deduction of less than 10 per cent). For a rare example of a discount of less than 10 per cent from the English case law, see Pasternack v Poulton [1973] 1 WLR 476 (5 per cent). 5 per cent deductions have also been made by courts in other jurisdictions where a similar legislative regime governs contributory negligence: see, eg, Snushall v Fulsang (2006) 258 DLR (4th) 425; Nominal Defendant v Rooskov [2012] NSWCA 43, (2012) 60 MVR 350. That deductions of less than 10 per cent are permissible (if unusual) has been accepted by the Court of Appeal: see Capps v Miller [1989] 1 WLR
} 
other end of the scale, the highest discount that was made for contributory negligence in our sample of claims was 100 per cent, and the next highest was 90 per cent. It has been argued that findings of 100 per cent contributory negligence are incoherent ${ }^{135}$ since the contributory negligence doctrine applies only when the damage suffered by the claimant is partly the fault of the defendant and partly the fault of the claimant, an analysis inconsistent with a finding that the claimant is entirely responsible for his or her injury. If this is correct, then the two claims in our sample where a judge purported to make a discount of 100 per cent for contributory negligence are best understood as decisions that on the facts the defendant's wrongful conduct was not causative of the injury in respect of which the claimant was bringing the claim. The discount of 90 per cent is not open to the same objection, but there was only one claim in our sample in which this discount was made, and the next highest discount made was 80 per cent (five claims), which bears out the claim that reductions in damages approaching 100 per cent are rare. ${ }^{136}$

\section{Two negative findings}

Sometimes the importance of empirical work lies in a finding that there is no significant association between variables, and there are a number of examples of such negative findings in our study. We wish to highlight two. The first is that it seems that it is very unlikely that the success rate of the plea of contributory negligence varies significantly across the categories of claim that account for the vast majority of personal injury claims in which contributory negligence is commonly pleaded, namely road accident claims, employers' liability claims, occupiers' liability claims and public liability claims. Secondly, we uncovered no evidence that in personal injury claims either the success rate of the plea of contributory negligence or the average discount varied significantly across the fifteen-year period of our study. We had thought that we might find some indications that judges had been harsher towards claimants who were alleged to be guilty of contributory negligence in time periods in which there was a heightened media and political focus on the so-called 'compensation culture', in particular 2003-2005 and 2009-2013. ${ }^{137}$ However, statistical analysis revealed no association

839, 848-849 (Croom-Johnson LJ) (cf Charlesworth \& Percy on Negligence (London: Sweet \& Maxwell, 13th ed, 2014) para 4-30).

135 See Pitts v Hunt [1991] 1 QB 24, 48 (Beldam LJ), 51 (Balcombe LJ); Brumder v Motornet Service and Repairs Ltd [2013] EWCA Civ 195, [2013] ICR 1069 at [4] (Beatson LJ); Goudkamp, n 134 above, 344-346.

136 Goudkamp, n 134 above, 348. For rare examples of discounts of 90 per cent or above in claims falling outside the scope of this study, see Hodkinson v Henry Wallwork \& Co Ltd [1995] 1 WLR 1195 (90 per cent); and Cummings v Murphy [1967] VR 865 (95 per cent deduction at trial not challenged on appeal).

${ }^{137}$ A crude but plausible measure of such focus is the number of stories in UK national newspapers in a given year that feature the phrase 'compensation culture'. A LexisNexis search produces the following figures for the years in our study period: 2000 (190), 2001 (279), 2002 (267), 2003 (297), 2004 (479), 2005 (297), 2006 (149), 2007 (146), 2008 (128), 2009 (129), 2010 (264), 2011 (292), 2012 (298), 2013 (381), 2014 (211). A trawl through the footnotes of some of the leading early academic literature on the compensation culture amply bears out the claim that there was a particular focus on this issue in the period 2003-2005: see, eg, K. Williams, 'State of Fear: Britain's “Compensation 
in personal injury claims between success rate or average discount and year. It appears that - as regards contributory negligence, at least - the judiciary are largely impervious to being influenced in the way that we thought possible. ${ }^{138}$

\section{CONCLUSION}

This article reports the findings of an empirical study of 368 first instance decisions on contributory negligence in England and Wales in the first fifteen years of this century. It offers the first such investigation of the contributory negligence doctrine carried out in a Commonwealth jurisdiction for over two decades, and is the only such study ever to have looked exclusively at judicial decisions. Perhaps the most important of our findings are as follows:

(1) The plea of contributory negligence succeeded in 60 per cent of the claims.

(2) Where a finding of contributory negligence was made, the average discount was 40.5 per cent.

(3) The most popular discounts were fractions that are commonly used in everyday life, namely, one-half, one-third and one-quarter. Although judges use essentially the full spectrum of discounts, discounts at the higher end of the spectrum are relatively infrequent. This latter finding is consistent with frequently expressed views to the same effect.

(4) Contrary to frequent and strident judicial statements to the contrary, it is doubtful that judges are especially reluctant to find claimants guilty of contributory negligence in employers' liability claims. We found no evidence of such reticence. However, when contributory negligence was found in this category of claim, the discount tended to be relatively small.

(5) Larger discounts from damages tend to be made in occupiers' liability claims than in other categories of claim that typically involve personal injury actions.

Culture" Reviewed' (2005) 25 LS 500; and A. Morris, 'Spiralling or Stabilising? The Compensation Culture and Our Propensity to Claim Damages for Personal Injury' (2007) 70 MLR 349. And a similar review of footnotes of a more recent book chapter evidences a renewed focus on the issue in media and political circles in 2009-2010 (which culminated at that end of that period in the publication of Lord Young of Graffham's report Common Sense, Common Safety for Prime Minister David Cameron): see A. Morris, 'The "Compensation Culture" and the Politics of Tort' in T.T. Arvind and J. Steele (eds), Tort Law and the Legislature: Common Law, Statute and the Dynamics of Legal Change (Oxford: Hart Publishing, 2013).

${ }^{138}$ For evidence that the attitudes of American jurors towards tort litigation are susceptible to media influence, see W. Haltom and M. McCann, Distorting the Law: Politics, Media and the Litigation Crisis (Chicago: The University of Chicago Press, 2004) 297-299. 
(6) Judges are very slow to find contributory negligence in professional negligence claims. However, when contributory negligence is found in such claims, the discount tends to be relatively high.

(7) Judges treat children aged over 10 more harshly than adult claimants, both when deciding whether to make a finding of contributory negligence and when determining the discount where contributory negligence has been found.

(8) We found no compelling evidence of a gender difference in relation to either the frequency with which contributory negligence is found or in terms of the size of the discount.

(9) In personal injury claims, both the success rate of the plea of contributory negligence and the size of the discounts imposed remained fairly constant during the study period.

As these findings demonstrate, our study uncovered several important truths about the contributory negligence doctrine hidden in the case law. Some of these findings cast significant doubt on the accuracy of widely held views about the doctrine's operation, while other findings suggest that some commonly expressed perceptions are accurate. Given the centrality of the contributory negligence doctrine in private law litigation, these findings are of considerable significance to both the study and the practice of private law. 


\section{Appendix}

The table below lists the 368 claims that comprise our sample for this study arranged by year of decision.

\section{0}

(1) Pritchard v Ralph 2000 WL 1791426; (2) Dingley v Bromley LBC [2000] CLY 4244;

(3) Marshall v Lincolnshire Roadcar Company 2000 WL 33116534; (4) Mv Parsons 2000 WL 33122496; (5) Mv Parsons 2000 WL 33122496 (6) Mullaney v Chief Constable of the West Midlands [2001] EWCA Civ 700; (7) Richard Simpson v A I Dairies Farms Ltd 2001 WL 14904; (8) Methven v Commissioner of the Police of the Metropolis 2000 WL 1480108; (9) Cook v Thorne [2001] EWCA Civ 81; (10) Cook v Thorne [2001] EWCA Civ 81; (11) Cottingham v Attey Bower \& Jones (a firm) [2000] PNLR 557; (12) Cottingham v Attey Bower \& Jones (a firm) [2000] PNLR 557; (13) Sousa v A\&J Bull Ltd [2001] EWCA Civ 1039 (14) North v TNT Express (UK) Ltd [2001] EWCA Civ 853; (15) Abouzaid v Mothercare (UK) Ltd 2000 WL 1918530; (16) Arnot v Sprake [2001] EWCA Civ 341; (17) Keyse $v$ The Commissioner of Police of the Metropolis 2000 WL 33201536; (18) Sbinhan Bank Ltd v Sea Containers Ltd [2000] 2 Lloyd's Rep 406; (19) Beckley v Crowther 2000 WL 1544758; (20) Watson v Skuse [2001] EWCA Civ 1158; (21) Ingram v Woodhouse [2001] EWCA Civ 1057; (22) Beech v Speare [2001] EWCA Civ 1164; (23) Parker v PFC Flooring Supplies Ltd [2001] PIQR P7; (24) Secretary of State for Environment, Transport and Regions v Unicorn Consultancy Services, Veale Wasbrough (a firm) [2000] NPC 108; (25) Markonski v Elson [2001] CLY 4477; (26) Ledger v Spurgeon [2001] EWCA Civ 1527; (27) Cross v UGC Ltd [2001] EWCA Civ 685; (28) DE (a child) v S Garages Ltd 2000 WL 33281292; (29) B (a child) v Wynn [2001] EWCA Civ 710 (30) Taylor v Tyler 2000 WL 33281237; (31) Regan v Chetwynd 2000 WL 33122388.

\section{1}

(32) Wv Hardman [2001] CLY 4452; (33) Gorringe v Calderdale MBC [2002] EWCA Civ 595; (34) Palfrey v Ark Offshore Ltd 2001 WL 34034706; (35) Betts v Tokley [2002] EWCA Civ 52; (36) Mattar v Shenouda 2001 WL 606384 (37) George v Stagecoach South East London 2001 WL 513089; (38) Perrin v Ministry of Defence [2001] All ER (D) 03 (May); (39) White v Chapman 2001 WL 825325; (40) Sullivan v HWF Ltd [2001] CLY 3301; (41) Toole v Bolton MBC [2002] EWCA Civ 588; (42) Anderson v Newham College for Further Education [2002] EWCA Civ 505, [2003] ICR 212; (43) Powell v Hansen 2001 WL 753470; (44) Logical Computer Supplies Ltd v Euro Car Parks Ltd 2001 WL 825094; (45) Young v Post Office [2002] EWCA Civ 661, [2002] IRLR 660; (46) Skerman v H Bollman Manufacturers Ltd [2002] EWCA Civ 919; (47) Chittock v Woodbridge School [2002] PIQR P13; (48) Oxley Plumbers Merchants v Davies [2002] EWCA Civ 540; (49) Holt v Holroyd Meek Ltd [2002] EWCA Civ 1004; (50) Imwin v Stevenson [2002] EWCA Civ 359; (51) Barnett v Scottish Power (t/ a Manweb Metering Business) [2002] EWCA Civ 104; (52) Pidgeon v Doncaster HA [2002] Lloyd's Rep 
Med 130; (53) Poccia v Toussaint 2001 WL 34008510; (54) Bailey v Command Security Services Ltd 2001 WL 1535385; (55) Bailey v Command Security Services Ltd 2001 WL 1535385; (56) Rowntree v Commissioner of the Police of the Metropolis 2001 WL 1346941; (57) Purdue v Devon Fire and Rescue Service [2002] EWCA Civ 1538; (58) Lunt v Khelifa 2001 WL 1479700; (59) Buyukardicli v Hammerson UK Properties Plc [2002] EWCA Civ 683; (60) Buyukardicli v Hammerson UK Properties Plc [2002] EWCA Civ 683; (61) Donaldson v Brighton DC 2001 WL 1743237; (62) Donaldson v Brighton DC 2001 WL 1743237; (63) Kane v New Forest DC (No 2) 2001 WL 1903436.

\section{2}

(64) Kearn-Price v Kent CC [2002] EWCA Civ 1539; (65) Butcher v Cornwall CC [2002] EWCA Civ 1640; (66) Wells v Trinder [2002] EWCA Civ 1030; (67) Arnesen v Heffey [2002] EWCA Civ 1058; (68) Beaton v Devon CC [2002] EWCA Civ 1675; (69); Adlington $v$ Commissioner of Police of the Metropolis [2002] EWCA Civ 1712; (70) Alpha Credit Bank v Stephenson Harwood (a firm) [2002] EWHC 922 (Ch); (71) Marshall v Rennocks [2004] CLY 2702; (72) Kiapasha (t/ a Takeaway Supreme) v Laverton [2002] EWCA Civ 1656; (73) Williams v Devon CC [2003] EWCA Civ 365; (74) Annabil v George Payne \& Co Ltd [2002] EWHC 1061 (QB); (75) Walkerv Newham LBC [2002] CLY 3256; (76) Credit Lyonnais $S A v$ Russell Jones \& Walker (a firm) [2002] EWHC 1310 (Ch), [2003] PNLR 2; (77) Pigford v Sunderland MDC [2003] EWCA Civ 823; (78) Donoghue v Folkestone Properties Ltd [2003] EWCA Civ 231; (79) Griffiths v Vauxhall Motors Ltd [2003] EWCA Civ 412; (80) Eagle v Chambers (No 1) [2003] EWCA Civ 1107, [2004] RTR 9; (81) Gartland v Hathaway Roofing Ltd [2003] EWCA Civ 957; (82) Gartland v Hathaway Roofing Ltd [2003] EWCA Civ 957; (83) Rogers v National Assembly for Wales [2004] EWCA Civ 250; (84) Adjei v King [2003] EWCA Civ 414; (85) Pratt v Smith 2002 WL 31676426; (86) Alexander Forbes Europe Ltd (formerly Nelson Hurst UK Ltd) v SBJ Ltd [2002] EWHC 3121 (Comm), [2003] PNLR 15.

\section{3}

(87) Cooper v Carillion Plc [2003] EWCA Civ 1811; (88) Taylor v Liverpool City Council [2004] CLY 2691; (89) Sabib Foods Ltd (in liquidation) v Paskin KyriaKides Sands (a firm) [2003] EWHC 142 (TCC), [2003] PNLR 30; (90) Speshal Investments Ltd v Corby Kane Howard Partnership Ltd (t/ a HBSV) [2003] EWHC 390 (Ch); (91) Constantine (t/a Tavistock Antiques) v Total Final Elf UK (formerly Total Oil Great Britain Ltd) [2003] EWHC 428 (Ch); (92) Moseley v Pell [2003] EWCA Civ 1533; (93) Battley v Thomson Holidays Ltd [2004] CLY 1878; (94) Marley v Cohen (t/ a Ribbon Plate Restaurant Boats) [2003] EWCA Civ 1536; (95) Plumpton v Norfolk CC [2004] CLY 2750; (96) Green v Bannister [2003] EWCA Civ 1819; (97) Coates v Jaguar Cars Ltd [2004] EWCA Civ 337; (98) Booth v White [2003] EWCA Civ 1708; (99) Costello v Birkby [2004] CLY 2744; (100); Wright v Romford Blinds \& Shutters Ltd [2003] EWHC 1165 (QB); (101) Barker v Corus UK Ltd [2006] UKHL 20, [2006] 2 AC 572; (102) Akasuc Enterprise Ltd v Farmar \& Shirreff [2003] EWHC 1275 (Ch); (103) Lamoon v Fry 
[2004] EWCA Civ 591; (104) Nixon v Thames Water Utilities Ltd [2006] CLY 2913; (105) Lennon v Commissioner of Police of the Metropolis [2004] EWCA Civ 130; (106) Cemm v Bryant [2004] CLY 2701; (107) Great North Eastern Railway Ltd v Railcare Ltd [2003] EWHC 1608 (Comm); (108) Gillespie v McFaddan McManus Construction Ltd [2003] EWHC 2067 (QB); (109) Owners of the Bow Spring v Owners of the Manzanillo II [2003] EWHC 1802 (Admlty), [2004] 1 Lloyd's Rep 647; (110) Six Continents Retail Ltd v Carford Catering Ltd [2003] EWCA Civ 1790; (111) Russell v Smith [2003] EWHC 2060 (QB); (112) Slattery v Moore Stephens (a firm) [2003] EWHC 1869 (Ch), [2004] PNLR 14; (113) Blake v Galloway [2004] EWCA Civ 814, [2004] 1 WLR 2844; (114) Burridge v Airwork Ltd [2004] EWCA Civ 459; (115) Houghton v Stannard [2003] EWHC 2666 (QB); (116) Edwards v Jerman [2004] CLY 2743.

\section{4}

(117) Home Office v Lowles [2004] EWCA Civ 985; (118) Brown v Vosper Thornycroft (UK) Ltd [2004] EWHC 400 (QB); (119) Hammond v Commissioner of Police of the Metropolis [2004] EWCA Civ 830; (120) Hammond v Commissioner of Police of the Metropolis [2004] EWCA Civ 830; (121) Parkinson v Chief Constable of Dyfed Powys [2004] EWCA Civ 802; (122) Hurst v Thomson Holidays Ltd [2004] CLY 1879; (123) Curran v Derbyshire and Lancashire Gliding Club [2004] EWHC 687 (QB); (124) Curran v Derbyshire and Lancashire Gliding Club [2004] EWHC 687 (QB); (125) Bici v Ministry of Defence [2004] EWHC 786 (QB); (126) Bici v Ministry of Defence [2004] EWHC 786 (QB); (127) Rose v South East London and Kent Bus Co Ltd [2004] EWHC 1106 (QB); (128) Eastgate v Oxfordshire CC [2005] CLY 1957; (129) Montlake v Lambert Smith Hampton Group Ltd [2004] EWHC 938 (Comm); (130) Bridgette Askey $v$ Wood [2005] EWCA Civ 574; (131) Lips v Older [2004] EWHC 1686 (QB); (132) Fagan v Jeffers [2005] EWCA Civ 380; (133) Firth v Hanley [2004] EWCA Civ 1714; (134) Swintonv Annabel's (Berkeley Square) Ltd [2005] CLY 2842; (135) Clarev Perry (t/a Widemouth Manor Hotel) [2005] EWCA Civ 39; (136) Morgan v Twyford Tots Nursery Ltd [2006] CLY 2912; (137) Goodchild v Organon Laboratories Ltd [2004] EWHC 2341 (QB); (138) Pesenti v London General Transport Services Ltd [2006] CLY 2903; (139) Pesenti v London General Transport Services Ltd [2006] CLY 2903; (140) Alli $v$ Luton \& Dunstable NHS Trust [2005] EWCA Civ 551; (141) Carpenter v Lunnon [2004] EWHC 3079 (QB); (142) Francis v Barclays Bank Plc [2004] EWHC 2787 (Ch), [2005] PNLR 18; (143) Dhillon v Aviation \& Airport Services Ltd 2004 WL 3520135.

\section{5}

(144) Baird v Thurrock BC [2005] EWCA Civ 1499; (145) Young v Kent CC [2005] EWHC 1342 (QB); (146) Davis v Stena Line Ltd [2005] EWHC 420 (QB), [2005] 2 Lloyd's Rep 13; (147) Honnor v Lewis [2005] EWHC 747 (QB); (148) Keown v Coventry Healthcare NHS Trust [2006] EWCA Civ 39; (149) Burgess v Plymouth CC [2005] EWCA Civ 1659, [2006] ICR 579; (150) Large v Mamani [2005] EWHC 1271 
(QB); (151) Whitehead v Thomson Holidays Ltd 2005 WL 3749695; (152) Smith v S Notaro Ltd [2006] EWCA Civ 775; (153) CTO Gesellschaft Fur Containertransport MBHand Co v Driennik [2006] EWCA Civ 1456; (154) Tompkins v Royal Mail Group Plc [2005] EWHC 1902 (QB), [2006] RTR 5; (155) Wells v Mutchmeats Ltd [2006] EWCA Civ 963; (156) Wells v Mutchmeats Ltd [2006] EWCA Civ 963; (157) Rodger v BHS Ltd [2006] CLY 1968; (158) Hodson Development Ltd v CTA Civils [2006] EWHC 1913 (TCC); (159) Shine v Tower Hamlets LBC [2006] EWCA Civ 852; (160) O'Gara v Paul John Construction (Leicester) Ltd [2005] EWHC 2829 (QB); (161) Davis v Schrogin [2006] EWCA Civ 974; (162) Feakins v Burstow [2005] EWHC 1936 (QB), [2006] PNLR 6; (163) Welsh v Messenger [2006] CLY 2875; (164) Badger v Ministry of Defence [2005] EWHC 2941 (QB), [2006] 3 All ER 173.

\section{6}

(165) Plymouth \& South West Co-operative Society v Architecture Structure \& Management Ltd [2006] EWHC 5 (TCC), (2006) 108 Con LR 77; (166) BP Plc v AON Ltd (No 2) [2006] EWHC 424 (Comm), [2006] 1 CLC 881; (167) Jukes v Etti [2006] EWHC 2493 (QB), [2007] RTR 2; (168) Ehrari (a child) v Curry [2006] EWHC 1319 (QB); (169) Pankhurst v White [2006] EWHC 2093 (Admin); (170) Willis v Nicolson [2007] EWCA Civ 199; (171) Nicolson v Willis [2006] EWHC 2402 (Admin); (172) Clark v Chief Constable of Essex [2006] EWHC 2290 (QB); (173) Crowther v Kirklees MDC [2007] CLY 2958; (174) Al Gouri v Acbkar [2007] CLY 3079; (175) B (a cbild) v JJB Sports Plc [2007] CLY 4195; (176) Evans v Kosmar Villa Holiday Plc [2007] EWCA Civ 1003, [2008] 1 WLR 297; (177) Dabinett v Somerset CC (Taunton County Court, 15 December 2006).

\section{7}

(178) Day v Suffolk CC [2007] EWCA Civ 1436; (179) Owners of the Ship Bulk Atalanta v Owners of the Ship Forest Pioneer [2007] EWHC 84 (Admlty); (180) Ellis v Wiliam Cook Leeds Ltd [2007] EWCA Civ 1232; (181) Gawler v Raettig [2007] EWHC 373 (QB); (182) N (a child) v Newham LBC [2007] CLY 2931; (183) Arbory Group Ltd $v$ West Craven Insurance Services [2007] Lloyd's Rep IR 491, [2007] PNLR 23; (184) Taylor v Rashid [2008] CLY 2661; (185) Keating v Wirral MBC [2008] CLY 2647; (186) Hanks v Ministry of Defence [2007] EWHC 966 (QB); (187); Carleton (Earl of Malmesbury) v Strutt \& Parker (a partnership) [2007] EWHC 999 (QB); (188) Ahanonu v South East London and Kent Bus Co Ltd [2008] EWCA Civ 274; (189) Wakeling v McDonagh [2007] EWHC 1201 (QB); (190) Garth v Grant (QBD, 25 May 2007); (191) Jones v BBC (QBD, 22 June 2007); (192) Jones v BBC (QBD, 22 June 2007); (193) Jones v BBC (QBD, 22 June 2007); (194) Newline Corporate Name Ltd v Morgan Cole (a firm) [2007] EWHC 1628 (Comm), [2008] PNLR 2; (195) Poppleton v Trustees of the Portsmouth Youth Activities Committee [2008] EWCA Civ 646; (196) Piccolo v Larkstock Ltd (t/a Chiltern Flowers) 2007 WL 2024863; (197) Dawes v Aldis [2007] EWHC 1831 (QB); (198) Sabakian v McDonnell [2007] EWHC 3242 (QB), [2008] RTR 19; (199) St George v Home Office [2007] EWHC 2774 (QB); (200) Gleeson 
v Court [2007] EWHC 2397 (QB), [2008] RTR 10; (201) Hughes v Guise Motors Ltd [2007] EWHC 2529 (QB); (202) Lindesay v Lamb [2007] EWHC 2948 (QB).

\section{8}

(203) Bollito v Arriva London [2008] EWHC 48 (QB); (204) Standard Life Assurance Ltd v Oak Dedicated Ltd [2008] EWHC 222 (Comm), [2008] 2 All ER (Comm) 916; (205) Greenwood v Cummings (QBD, 9 April 2008); (206) Parmer v Big Security Co Ltd [2008] EWHC 1414 (QB); (207); Heaton v Herzog [2008] EWCA Civ 1636, [2009] RTR 30; (208) Lees v Northamptonshire Heartlands NHS Primary Care Trust [2008] EWHC 2484 (QB); (209) Shortell v BICAL Construction Ltd (QBD, 16 May 2008); (210) Minh Lac v Clayton [2009] EWCA Civ 106; (211) Minh Lac v Clayton [2009] EWCA Civ 106; (212) Minh Lac v Clayton [2009] EWCA Civ 106; (213) Clayton v Lambert [2009] EWCA Civ 237; (214) Gower-Smith v Hampshire CC (Southampton County Court, 27 June 2008); (215) Flavio v Jeffrey [2008] EWHC 2331 (QB); (216) Armsden v Kent Police [2009] EWCA Civ 631, [2009] RTR 31; (217) Ministry of Defence v Radclyffe [2009] EWCA Civ 635; (218) Sowmez v Kababerry Wholesale Ltd [2008] EWHC 3366 (QB); (219) Williams v Jervis [2008] EWHC 2346 (QB); (220) Kern v Bridgend CBC (Bridgend County Court, 17 October 2008); (221) CollinsWilliamson v Silverlink Train Services Ltd [2008] EWHC 2945 (QB); (222) Craggy v Chief Constable of Cleveland Police [2009] EWCA Civ 1128; (223) Buchan v Whiting [2008] EWHC 2951 (QB); (224) Anderson v Lyotier (t/a Snowbiz:) [2008] EWHC 2790 (QB); (225) Palmer v Kitley [2008] EWHC 2819 (QB); (226) Crew v Ash [2008] EWHC 3068 (QB).

\section{9}

(227) Callier v Deacon [2009] EWHC 245 (QB); (228) Smith v Finch [2009] EWHC 53 (QB); (229) Spencer v Wincanton Holdings Ltd [2009] EWCA Civ 1404; (230) Nationwide Buildings Society v Dunlop Haywards (DHL) Ltd (t/ a Dunlop Heywood Lorenz) [2009] EWHC 254 (Comm), [2010] 1 WLR 258; (231) Stanton v Collinson [2009] EWHC 342 (QB); (232) Drew v Whitbread [2010] EWCA Civ 53; (233) Russell v West Sussex CC [2009] EWHC 1063 (QB); (234) Chubb Fire Ltd v Vicar of Spalding [2010] EWCA Civ 981, [2010] 2 CLC 277; (235) Taylor v Wincanton Group Ltd [2009] EWCA Civ 1581; (236) Osei-Antwi v South East London \& Kent Bus Co [2010] EWCA Civ 132; (237) Dines v Clifton [2009] EWHC 1254 (QB); (238) Tibbatts v British Airways Plc [2009] EWHC 815 (QB); (239) Stanley v Close (t/ a Armthorpe Moto Parc) [2009] EWHC 2849 (QB); (240) The Owners, Demise Charters and Time Charterers of the Ship 'Western Neptune' $v$ The Owners and Demise Charterers of the Ship Philadelphia Express' [2009] EWHC 1274 (Admlty), [2010] 2 All ER (Comm) 154; (241) Berry v Laytons [2009] EWHC 1591 (QB); (242) Bell v Havering LBC [2010] EWCA Civ 689; (243) Martin v Triggs Turner Bartons (a firm) [2009] EWHC 1920 (Ch), [2010] PNLR 3; (244) Smith v Hammond [2010] EWCA Civ 725; (245) Bhatt v Fontain Motors Ltd [2010] EWCA Civ 863; (246) Toropdar v D [2009] EWHC 2997 (TCC); (247) Levers v Prebble [2010] EWCA Civ 1615; (248) Harvey v Plymouth City Council [2010] EWCA 
Civ 860; (249) Horsley v Cascade Insulation Services Ltd [2009] EWHC 2945 (QB); (250) Horsley v Cascade Insulation Services Ltd [2009] EWHC 2945 (QB); (251) Dunlop Haywards Ltd v Barbon Insurance Group Ltd [2009] EWHC 2900 (Comm), [2010] Lloyd's Rep IR 149; (252) Dunlop Haywards Ltd v Barbon Insurance Group Ltd [2009] EWHC 2900 (Comm), [2010] Lloyd's Rep IR 149; (253) Sklair v Haycock [2009] EWHC 3328 (QB); (254) Howe v Houlton [2009] EWHC 3344 (QB).

\section{0}

(255) Scout Association v Barnes [2010] EWCA Civ 1476; (256) Limbrick v Ron Green \& Son [2010] CLY 2413; (257) Moore v Hotelplan Ltd (t/ a Inghams Travel) [2010] EWHC 276 (QB); (258) Waters v Hayley [2010] EWHC 920 (QB); (259) Tom Hoskins Plc v EMR Law (a firm) [2010] EWHC 479 (Ch); (260) Edwards v Martin [2010] EWHC 570 (QB); (261) Dalling v R J Heale \& Co Ltd [2011] EWCA Civ 365; (262) Stoddart v Perucca [2011] EWCA Civ 290; (263) Ceva Logistics Ltd v Lynch (t/ a SW Lynch Electrical Contractors) [2011] EWCA Civ 188, [2011] ICR 746; (264) Ceva Logistics Ltd v Lynch (t/ a SW Lynch Electrical Contractors) [2011] EWCA Civ 188, [2011] ICR 746; (265) Tolley v Carr [2010] EWHC 2191 (QB), [2011] RTR 7; (266) Tolley v Carr [2010] EWHC 2191 (QB), [2011] RTR 7; (267) Tolley v Carr [2010] EWHC 2191 (QB), [2011] RTR 7; (268) Caerphilly CBC v Button [2010] EWCA Civ 1311, [2011] ICR D3; (269) Swain v Geoffrey Osborne Ltd [2010] EWHC 1108 (QB); (270) Swain v Geoffrey Osborne Ltd [2010] EWHC 1108 (QB); (271) Willard v Boswell [2010] EWHC 2037 (QB); (272) Kotula v EDF Energy Networks (EPN) Plc [2010] EWHC 1968 (QB); (273) Belka v Prosperini [2011] EWCA Civ 623; (274) Clark v Bourne Leisure Ltd [2011] EWCA Civ 753; (275) Scullion v Bank of Scotland Plc (t/ a Colleys) [2010] EWHC 2253 (Ch); (276) Withers LLP v Harrison [2010] EWHC 2769 (QB); (277) Boardman v Ministry of Defence (QBD, 12 November 2010); (278) Burton v Evitt [2001] EWCA Civ 1378; (279) Hill $v$ Master Concrete Ltd [2010] EWHC 3613 (QB).

\section{1}

(280) Smith v Chief Constable of Nottinghamshire [2012] EWCA Civ 161, [2012] RTR 23; (281) Hadlow v Peterborough City Council [2011] EWCA Civ 1329; (282) Sedge v Prime [2011] EWHC 820 (QB); (283) Lightfoot v Go-Ahead Group Plc [2011] EWHC 89 (QB), [2011] RTR 27; (284) Ground Gilbey Ltd v Jardine Lloyd Thompson UK Ltd [2011] EWHC 124 (Comm), [2012] Lloyd's Rep IR 12; (285) Douglas v O’Neill [2011] EWHC 601 (QB); (286) Maynard v Wigan MBC [2011] EWCA Civ 1694; (287) Phethean-Hubble v Coles [2011] EWHC 363 (QB); (288) Peverill v Hillingdon LBC (Central London County Court, 9 March 2011); (289) Re P (Deceased) [2011] EWHC 1266 (QB); (290) Thomas v Warwickshire CC [2011] EWHC 772 (QB); (291) Rehill v Rider Holdings Ltd [2012] EWCA Civ 628, [2013] RTR 5; (292) Stangroom v Brown [2012] EWCA Civ 424; (293) Cheung v Zhu (t/ a Yang Sing Sing and Chip) [2011] EWHC 2913 (QB); (294) Tafa v Matsim Properties Ltd [2011] EWHC 1302 (QB); (295) Tafa v Matsim Properties Ltd [2011] EWHC 1302 (QB); (296) Costa v Imperial 
London Hotels Ltd [2012] EWCA Civ 672; (297) Whiteford v Kubas UAB [2012] EWCA Civ 1017; (298) Woodham v JM Tumer (t/a Turners of Great Barton) [2011] EWHC 1588 (QB), [2012] RTR 7; (299) Brown v Brent (Croydon County Court, 21 June 2011); (300) Coldridge v Bury MBC (Manchester County Court, 24 June 2011); (301) Harrison v Jagged Globe (Alpine) Ltd [2012] EWCA Civ 835; (302) Reynolds v Strutt \& Parker LLP [2011] EWHC 2263 (QB); (303) Trebor Bassett Holdings Ltd v ADT Fire \& Security Plc [2011] EWHC 1936 (TCC), [2011] BLR 661; (304) Trebor Bassett Holdings Ltd v ADT Fire \& Security Plc [2012] EWCA Civ 1158, [2012] BLR 441; (305) Ellis v Lokat (QBD, 6 October 2011); (306) Johnson v Castle Combe Circuit Ltd (QBD, 7 October 2011); (307) Devereux v Hayward [2011] EWHC 2780 (QB); (308) McDermott v Pettit [2011] EWHC 3074 (QB); (309) Malasi v Attmed [2011] EWHC 4083 (QB); (310) Palfrey v VM Morrisons Supermarkets Plc [2012] EWCA Civ 1917.

\section{2}

(311) Ringe v Eden Springs (UK) Ltd [2012] EWHC 14 (QB); (312) Rehman v Brady [2012] EWHC 78 (QB); (313) Paramasivan v Wicks [2013] EWCA Civ 262; (314) Tavares v Hudson-Rotin [2012] EWHC 3171 (QB); (315) Pinchbeck v Craggy Island Ltd [2012] EWHC 2745 (QB); (316) AC v Devon CC [2012] EWHC 796 (QB), [2012] RTR 32; (317) Tacagni v Cornwall CC [2013] EWCA Civ 702; (318) Argos Ltd v Leather Trade House Ltd (formerly BLC Leather Technology Centre Ltd) [2012] EWHC 1348 (QB); (319) Starks v Chief Constable of Hertfordshire [2013] EWCA Civ 782, [2014] RTR 4; (320) Meaney v Link Rider Coaches Ltd (Bournemouth County Court, 21 June 2012); (321) Hannon v Hillingdon Homes Ltd [2012] EWHC 1437 (QB); (322) Hook v Eatons Solicitors (Leeds County Court 17 July 2012); (323) Ireland $\checkmark$ David Lloyd Leisure Ltd [2013] EWCA Civ 665; (324) Condie v Blight (Newcastle upon Tyne County Court, 25 July 2012); (325) Beasley v Alexander [2012] EWHC 2197 (QB); (326) Probert v Moore [2012] EWHC 2324 (QB); (327) Alleyne v Commissioner of the Police of the Metropolis [2012] EWHC 3955 (QB); (328) McCarrick v Park Resorts Ltd (QBD, 26 October 2012); (329) West Sussex CC v Pierce [2013] EWCA Civ 1230; (330) Japp v Virgin Holidays Ltd [2013] EWCA Civ 1371; (331) The Personal Representatives of the Estate of Cyril Biddick (Deceased) v Morcom [2014] EWCA Civ 182; (332) Webb Resolutions Ltd v ESurv Ltd [2012] EWHC 3653 (TCC), [2013] PNLR 15; (333) Blemain Finance Ltd v ESurv Ltd [2012] EWHC 3654 (TCC).

\section{3}

(334) Ayres v Odedra [2013] EWHC 40 (QB); (335) Wheeler v Chief Constable of Gloucestershire [2013] EWCA Civ 1791; (336) Germaine v Epsom and St Helier University Hospitals NHS Trust [2013] EWHC 761 (QB); (337) Wilson v Haden (t/ a Clyne Farm Centre) [2013] EWHC 229 (QB); (338) Sharp v Top Flight Scaffolding Ltd [2013] EWHC 479 (QB); (339) Rockliffe v Liverpool City Council (Liverpool County Court 19 March 2013); (340) Gray v Gibson [2014] EWCA Civ 355; (341) Corbett v Cumbria Kart Racing Club [2013] EWHC 1362 (QB); (342) Corbett v Cumbria Kart Racing Club 
[2013] EWHC 1362 (QB); (343) Hickman v London Central Bus Co Ltd [2013] EWHC 1703 (QB); (344) Mills v JP Barnes \& Sons Ltd 2013 WL 8182338; (345) Ali $v$ Caton [2013] EWHC 1730 (QB); (346) Wembridge Claimants v Winter [2013] EWHC 2331 (QB); (347) Bennett v Southwell [2013] EWHC 2382 (QB); (348) Khan v Harrow LBC [2013] EWHC 2687 (TCC), [2013] BLR 611; (349) Khan v Harrow LBC [2013] EWHC 2687 (TCC), [2013] BLR 611; (350) Forsta AP-Fonden v Bank of New York Mellon SA/NV [2013] EWHC 3127 (Comm); (351) Nadarajah v Sotnick [2013] EWHC 3389 (QB); (352) Everett v London Fire and Emergency Planning Authority [2013] All ER (D) 289 (Nov); (353) McCracken v Smith [2013] EWHC 3620 (QB); (354) Butcher v Southend-on-Sea BC [2014] EWCA Civ 1556; (355) Jones v Lawton [2013] EWHC 4108 (QB).

\section{4}

(356) Train v Secretary of State for Defence [2014] EWHC 1928 (QB); (357) Wellesley Partnership LLP v Withers LLP [2014] EWHC 556 (Ch), [2014] PNLR 22; (358) Curtis v Hertfordshire Council [2014] EWHC 1672 (QB); (359) MacLeod v Commissioner of the Police of the Metropolis [2014] EWHC 977 (QB); (360) Rainford v Lawrenson [2014] EWHC 1188 (QB); (361) West Sussex CC v Fuller [2015] EWCA Civ 189; (362) Groves v Studley [2014] EWHC 1522 (QB); (363) Terminal Contenitori Porto di Genova SpA v China Shipping Container Lines Ltd [2014] EWHC 1629 (Comm); (364) Group Seven Ltd v Allied Investment Corp Ltd [2014] EWHC 2046 (Ch); (365) Playboy Club London Ltd v Banca Nazionale Del Lavoro SPA [2014] EWHC 2613 (QB); (366) Blackmore v Department for Communities and Local Government 2014 WL 5411779; (367) Wormald v Ahmed [2014] EWHC 4498 (QB); (368) Edwards v Sutton LBC [2014] EWHC 4378 (QB). 